\title{
The significance of selected tree species age in their efficiency in elements phytoextraction from wastes mixture
}

\author{
M. Mleczek ${ }^{1}$ P. Rutkowski ${ }^{2}$ J. Kaniuczak ${ }^{3} \cdot$ M. Szostek $^{3} \cdot$ A. Budka ${ }^{4} \cdot$ Z. Magdziak ${ }^{1} \cdot$ S. Budzyńska ${ }^{1}$. \\ N. Kuczyńska-Kippen ${ }^{5} \cdot$ P. Niedzielski ${ }^{6}$
}

Received: 28 June 2018 / Revised: 27 July 2018 / Accepted: 4 September 2018 / Published online: 15 September 2018

(c) The Author(s) 2018

\begin{abstract}
The phytoextraction of toxic elements present in industrial wastes by selected tree species seems to offer an interesting alternative to hyperaccumulators, which are generally highly effective but small. For this reason, the study aimed to compare the potential of 1- and 2-year-old Tilia cordata Miller and Ulmus laevis Pall seedlings growing on a mixture of wastes (flotation tailings and sewage sludges) in the environment. One-year-old $T$. cordata was the only plant unable to grow successfully. A general decrease in tree biomass was observed following their growth on the waste mixture. The mean biomass of 2-year-old T. cordata and $U$. laevis seedlings was $59.5 \pm 1.6$ and $57.0 \pm 8.6 \mathrm{~g}$, respectively, whereas that of 1-year-old $T$. cordata was $16.0 \pm 9.3 \mathrm{~g}$. These values were $46.2,48.0$ and $50.5 \%$ lower than those determined for the control trees. Phytoextraction of 67 elements in particular organs of trees in many cases was significantly diverse. According to the Friedman rank sum test, T. cordata $(1 \mathrm{y})$ and $U$. laevis $(2 \mathrm{y})$ growing in soil were the only plants that differed as regards their ability to phytoextract elements. In the case of trees growing on the waste mixture, the most effective accumulating plants were seedlings of 2-yearold $T$. cordata. Significantly lower efficiency was observed for 2-year-old $U$. laevis, while the lowest efficiency was recorded for 1-year-old T. cordata. The obtained results unambiguously pointed to the significant role of a proper selection of tree species concerning their age for phytoextraction of elements from polluted substrates.
\end{abstract}

Keywords Flotation tailings $\cdot$ Heavy metal $\cdot$ Phytoremediation $\cdot$ Mining sludge $\cdot$ Tree species

Editorial responsibility: Shahid Hussain.

M. Mleczek

miroslaw.mleczek@up.poznan.pl

1 Department of Chemistry, Poznań University of Life Sciences, Wojska Polskiego 75, 60-625 Poznan, Poland

2 Department of Forest Sites and Ecology, Poznań University of Life Sciences, Wojska Polskiego 71F, 60-625 Poznan, Poland

3 Department of Soil Science, Environmental Chemistry and Hydrology, University of Rzeszów, Zelwerowicza 8b, 35-601 Rzeszow, Poland

4 Department of Mathematical and Statistical Methods, Poznan University of Life Sciences, Wojska Polskiego 28, 60-637 Poznan, Poland

5 Faculty of Biology, Department of Water Protection, Adam Mickiewicz University, Umultowska 89, 61-614 Poznan, Poland

6 Faculty of Chemistry, Adam Mickiewicz University in Poznań, Umultowska 89B, 61-614 Poznan, Poland

\section{Introduction}

Heavy metals are one of the most considerable ecological problems; they are mainly related to the anthropogenic activity (Chen et al. 2014; Saba et al. 2015). An increase in the concentration of these elements in the environment causes changes in natural processes that influence the proper functioning of a variety of ecosystems (Theriault and Nkongogo 2016). For this reason, it is essential to control the number of toxic elements transported directly to the environment. The problem of heavy metal discharge becomes particularly acute when it negatively affects humans, causing many health risks associated with it (Järup 2003; Pan et al. 2016; Xin et al. 2015). In conditions where high amounts of toxic elements are stored, there is an ever-present risk, and it is important that appropriate methods are adopted to minimise the negative influence of these elements. Such protective measures include the implementation of biological methods such as phytoremediation. Being a cost-effective, longlasting and aesthetic solution, it offers quite a high efficiency 
after the fulfilment of some fundamental conditions (Nie et al. 2016).

In unfavourable environmental conditions, plant growth is usually related to a decrease of biomass crop, ability to adapt and survive (Erdemir et al. 2016; Yasar et al. 2010), with a simultaneously higher phytoextraction of elements, which is related to the higher amount of their bioavailable forms (Makgalaka-Matlala et al. 2008). The selection of suitable plants, i.e. those that are resistant, effective accumulators of toxic elements and characterised by high biomass, is not an easy process as there are numerous possible interactions with respect to plant-soil (e.g. associations with beneficial soil microorganisms, variation in the root architecture) and specific habitat requirements (amount of real level of nutritional elements, water needs, etc.).

The diversity in plant survival under conditions of toxic element presence is still not well understood, especially in the case of common wood tree species, for which the literature data are limited. Most studies have been carried out on short-lived herbaceous species or plants characterised by low biomass crop (Chen et al. 2014; Wei et al. 2006). Trees are not plants that are highly resistant to high metal contamination, but they can survive in such disadvantageous environments as toxic mine soil (Marchiol et al. 2004). The higher tolerance of trees may be indicative of the evolution of constitutive tolerance. Hence, selecting appropriate tree species is crucial for achieving successful phytostabilisation (van Nevel et al. 2011), or metal phytoextraction (Saba et al. 2015). Trees are characterised by well-developed root systems and high transpiration capacity (Pulford and Watson, 2003; van Nevel et al. 2011); specific traits allow them to improve their efficiency in toxic element leaching as regards soil acidification and production of dissolved organic matter (Mayer 1998; van Nevel et al. 2011). Moreover, their natural lifespan is much longer than that of herbaceous plants. Thus, trees may potentially be more efficient in a long-term process of environmental purification.

It is known that Populus and Salix accumulate cadmium (Cd) and/or zinc ( $\mathrm{Zn}$ ) in their biomass (root, branches, leaves and wood tissues) at higher concentrations than other tree species (Goliński et al. 2015; Hassinen et al. 2009), while birches (Betula spp.) are known as Zn accumulators (Van Nevel et al. 2011). On the other hand, other tree species such as Alnus, Fraxinus or Sorbus are characterised by their exclusion of metals and clear limitation of their transport to aerial plant parts (Rosselli et al. 2003). Mertens et al. (2004) investigated five tree species (Acer pseudoplatanus L., Alnus glutinosa L. Gaertn., Fraxinus excelsior L., Populus alba L. and Robinia pseudoacacia L.); R. pseudoacacia and P. alba were found to have the highest growth rates, $F$. excelsior, A. pseudoplatanus and A. glutinosa had the highest survival rates (90\%), but showed stunted growth, while poplar characterised the highest concentration of $\mathrm{Cd}\left(8.0 \mathrm{mg} \mathrm{kg}^{-1}\right)$ and $\mathrm{Zn}$ $\left(465 \mathrm{mg} \mathrm{kg}^{-1}\right)$ in its leaves. It is worth noting that these two metals are generally transported gradually from the roots to aerial parts (twigs, leaves) via transpiration flow. The efficiency of uptake and/or translocation of these elements may be dependent on many other elements (MacFarlane et al. 2007; Takenaka et al. 2009) or the general influence of environmental factors such as $\mathrm{pH}$, cation exchange capacity (CEC), clay component or redox potential (Magdziak et al. 2015). Trees, like many other plants, are able to mobilise different defence mechanisms during their exposure to the presence of toxic elements. For this reason, the mechanisms of metal accumulation may also differ using specific transporters as, e.g. AtIRT1 and AtIRT2 in Arabidopsis or ZIP genes involved in Fe and Zn transport in Thlaspi caerulescens (Plaza et al. 2007; Vert et al. 2002) to uptake and translocate metals. Extraction of metal(loid)s by trees can be also related to an increase or decrease many other elements that are components of transporters, as, for example, described in the studies of Budzyńska et al. (2017), where phytoextraction of arsenite in Acer, Betula, Quercus and Ulmus was the cause of a significant decrease of boron (B) and silicon ( $\mathrm{Si}$ ) content in their roots.

However, the literature data suggest that they are likely to be most effective on slightly contaminated soils and less appropriate for detoxifying soils with high concentrations of heavy metals (Brunner et al. 2008; Mertens et al. 2004). Literature data also describe exposure to higher metal concentrations in (for example, pedunculate oak (Quercus robur L.), sessile oak (Q. petraea (Matt.) Liebl.), Scots pine (Pinus sylvestris L.), Corsican pine (Pinus nigra ssp. Laricio Maire), black locust (Robinia pseudoacacia L.), beech (Fagus sylvatica L.) and Aspen (Populus tremula L.). However, such studies focus on only two selected metals at different doses, in conjunction with toxicity studies, and under controlled condition (Theriault and Nkongogo 2016; Unterbrunner et al. 2007). Data on metal accumulation for native tree or scrub species in extremely polluted soils or wastes are negligible (Mleczek et al. 2017, 2018).

Trees cannot survive on wastes extremely polluted with heavy metals and specific physicochemical traits. However, mixing different mining wastes and the use of selected plant species and age can be a promising way to resolve this problem. For this reason, the main objective of this study was to compare the potential ability of one- and two-year-old seedlings of two tree species (Tilia cordata Miller and Ulmus laevis Pall) growing on a mixture of highly polluted mining wastes to uptake and translocate selected elements to their roots, stems, and leaves and to evaluate their biomass crop. 


\section{Materials and methods}

\section{Experimental materials}

On April 11, 2016, ten specimens of each 1-year (1y)- and 2-year (2y)-old Ulmus laevis Pall (White elm) and 1- and 2-year-old Tilia cordata Miller (Linden) were collected from the forest nursery of the Pniewy Forest Division $\left(52^{\circ} 29^{\prime} 04^{\prime} \mathrm{N} 16^{\circ} 15^{\prime} 28^{\prime} \mathrm{E}\right)$. The choice of plant species was influenced by the results of the authors' earlier experiments (Mleczek et al. 2016, 2017).

\section{Experiment design}

The tested tree seedlings used in the experiment were chosen after their preliminary selection for plants with similar biomass, height and root system for trees of the same age. Ten specimens of each tree species of both ages (40 plants in the experiment) were planted in the waste
Table 1 Concentration of elements $\left[\mathrm{mg} \mathrm{kg}^{-1} \mathrm{DW}\right]$ in substrates used in experiment

\begin{tabular}{|c|c|c|c|c|}
\hline Element & Soil $(c)$ & Mining sludge & Flotation tailing & Waste mixture $\left(w_{\mathrm{m}}\right)$ \\
\hline $\mathrm{Ag}$ & $\mathrm{bDL}$ & $17.5^{\mathrm{a}} \pm 1.10$ & $8.52^{c} \pm 0.62$ & $13.2^{\mathrm{b}} \pm 1.52$ \\
\hline $\mathrm{Al}$ & $460^{c} \pm 21$ & $0.38^{\mathrm{d}} \pm 0.04$ & $4733^{\mathrm{a}} \pm 378$ & $2397^{\mathrm{b}} \pm 125$ \\
\hline As & $0.18^{\mathrm{c}} \pm 0.02$ & $2.26^{\mathrm{a}} \pm 0.15^{*}$ & $25.0^{\mathrm{b}} \pm 1.16$ & $1.15^{\mathrm{a}} \pm 0.07^{*}$ \\
\hline B & $1.51^{\mathrm{c}} \pm 0.17$ & $0.33^{\mathrm{d}} \pm 0.06$ & $49.4^{\mathrm{a}} \pm 3.94$ & $23.9^{\mathrm{b}} \pm 1.02$ \\
\hline $\mathrm{Ba}$ & $5.92^{\mathrm{d}} \pm 0.42$ & $48.8^{c} \pm 3.95$ & $196^{\mathrm{a}} \pm 14$ & $129^{\mathrm{b}} \pm 15.3$ \\
\hline $\mathrm{Be}$ & $\mathrm{bDL}$ & $0.08^{c} \pm 0.01$ & $0.89^{\mathrm{a}} \pm 0.05$ & $0.51^{\mathrm{b}} \pm 0.14$ \\
\hline $\mathrm{Bi}$ & $\mathrm{bDL}$ & $0.11^{\mathrm{c}} \pm 0.02$ & $0.90^{\mathrm{a}} \pm 0.03$ & $0.46^{\mathrm{b}} \pm 0.11$ \\
\hline $\mathrm{Ca}$ & $3049^{\mathrm{d}} \pm 286$ & $86151^{\mathrm{c}} \pm 4688$ & $197693^{\mathrm{a}} \pm 1818$ & $146163^{\mathrm{b}} \pm 15279$ \\
\hline $\mathrm{Cd}$ & $0.18^{\mathrm{d}} \pm 0.04$ & $21.2^{\mathrm{a}} \pm 0.44$ & $7.86^{\mathrm{c}} \pm 0.56$ & $14.6^{\mathrm{b}} \pm 2.03$ \\
\hline $\mathrm{Ce}$ & $1.22^{\mathrm{d}} \pm 0.05$ & $87.2^{\mathrm{a}} \pm 0.93$ & $22.1^{\mathrm{c}} \pm 3.15$ & $52.4^{\mathrm{b}} \pm 4.87$ \\
\hline Co & $2.57^{\mathrm{c}} \pm 0.51$ & $0.62^{\mathrm{d}} \pm 0.01$ & $39.3^{\mathrm{a}} \pm 0.99$ & $20.5^{\mathrm{b}} \pm 1.37$ \\
\hline $\mathrm{Cr}$ & $7.07^{\mathrm{d}} \pm 1.51$ & $220^{\mathrm{a}} \pm 4.79$ & $83.4^{\mathrm{c}} \pm 5.77$ & $157^{\mathrm{b}} \pm 10.8$ \\
\hline $\mathrm{Cu}$ & $14.2^{\mathrm{d}} \pm 1.84$ & $4798^{\mathrm{a}} \pm 14.70$ & $2069^{c} \pm 30.7$ & $3466^{\mathrm{b}} \pm 274$ \\
\hline $\mathrm{Fe}$ & $10762^{\mathrm{d}} \pm 2034$ & $37133^{a} \pm 908$ & $15970^{c} \pm 392$ & $26862^{b} \pm 4212$ \\
\hline $\mathrm{Ge}$ & $\mathrm{bDL}$ & $11.2^{\mathrm{a}} \pm 0.78$ & $0.16^{\mathrm{c}} \pm 0.03$ & $5.74^{\mathrm{b}} \pm 1.02$ \\
\hline In & $0.12^{\mathrm{d}} \pm 0.03$ & $2.12^{\mathrm{a}} \pm 0.09$ & $0.30^{c} \pm 0.02$ & $1.28^{\mathrm{b}} \pm 0.20$ \\
\hline K & $657^{\mathrm{c}} \pm 5.12$ & $487^{\mathrm{d}} \pm 42.1$ & $5443^{\mathrm{a}} \pm 110$ & $3986^{\mathrm{b}} \pm 254$ \\
\hline $\mathrm{Li}$ & $0.28^{c} \pm 0.03$ & $13.2^{\mathrm{b}} \pm 0.14$ & $21.3^{\mathrm{a}} \pm 2.41$ & $17.9^{\mathrm{a}} \pm 2.04$ \\
\hline $\mathrm{Lu}$ & $\mathrm{bDL}$ & $0.90 \mathrm{a} \pm 0.06$ & $0.30^{\mathrm{c}} \pm 0.02$ & $0.56^{\mathrm{b}} \pm 0.11$ \\
\hline $\mathrm{Mg}$ & $1145^{\mathrm{d}} \pm 74.8$ & $5832^{c} \pm 105$ & $27228^{a} \pm 107$ & $21036^{\mathrm{b}} \pm 985$ \\
\hline $\mathrm{Mn}$ & $175^{\mathrm{d}} \pm 3.53$ & $523^{c} \pm 3.30$ & $1166^{\mathrm{a}} \pm 12.7$ & $882^{\mathrm{b}} \pm 74$ \\
\hline $\mathrm{Na}$ & $110^{c} \pm 24.4$ & $952^{\mathrm{a}} \pm 124$ & $786^{\mathrm{b}} \pm 12.9$ & $842^{\mathrm{ab}} \pm 56$ \\
\hline $\mathrm{Nd}$ & $2.77^{\mathrm{d}} \pm 0.26$ & $53.6^{\mathrm{c}} \pm 4.11$ & $112^{\mathrm{a}} \pm 8.95$ & $86.6^{\mathrm{b}} \pm 5.98$ \\
\hline $\mathrm{Ni}$ & $8.69^{\mathrm{d}} \pm 1.34$ & $506^{\mathrm{a}} \pm 2.09$ & $74.1^{\mathrm{c}} \pm 3.37$ & $286^{\mathrm{b}} \pm 46$ \\
\hline $\mathrm{Pb}$ & $36.5^{\mathrm{d}} \pm 11.2$ & $5742^{a} \pm 52$ & $1513^{c} \pm 39.1$ & $3452^{\mathrm{b}} \pm 138$ \\
\hline $\operatorname{Pr}$ & bDL & $0.11^{c} \pm 0.02$ & $0.68^{\mathrm{a}} \pm 0.07$ & $0.39^{\mathrm{b}} \pm 0.05$ \\
\hline $\mathrm{Pt}$ & $0.04^{\mathrm{d}} \pm 0.01$ & $4.32^{c} \pm 1.51$ & $32.3^{\mathrm{a}} \pm 5.62$ & $18.4^{\mathrm{b}} \pm 4.12$ \\
\hline $\mathrm{Sc}$ & $5.91^{\mathrm{ab}} \pm 0.82$ & $3.53^{\mathrm{c}} \pm 0.41$ & $7.30^{\mathrm{a}} \pm 1.03$ & $5.32^{\mathrm{b}} \pm 0.87$ \\
\hline $\mathrm{Sr}$ & $1.32^{\mathrm{d}} \pm 0.27$ & $77.3^{c} \pm 4.1$ & $571^{\mathrm{a}} \pm 42.8$ & $308^{\mathrm{b}} \pm 28.6$ \\
\hline $\mathrm{Ta}$ & bDL & $1.79^{c} \pm 0.21$ & $3.21^{\mathrm{a}} \pm 0.17$ & $2.45^{\mathrm{b}} \pm 0.41$ \\
\hline $\mathrm{Tl}$ & bDL & $472^{\mathrm{a}} \pm 16.7$ & $0.83^{c} \pm 0.06$ & $241^{\mathrm{b}} \pm 32$ \\
\hline $\mathrm{Tm}$ & bDL & $2.25^{\mathrm{a}} \pm 0.14$ & $0.75^{\mathrm{c}} \pm 0.03$ & $1.53^{\mathrm{b}} \pm 0.25$ \\
\hline $\mathrm{U}$ & $\mathrm{bDL}$ & $0.06^{\mathrm{b}} \pm 0.01$ & $0.14^{\mathrm{a}} \pm 0.02$ & $0.11^{\mathrm{a}} \pm 0.02$ \\
\hline $\mathrm{V}$ & $26.8^{\mathrm{c}} \pm 2.51$ & $38.7^{\mathrm{b}} \pm 4.56$ & $72.1^{\mathrm{a}} \pm 6.69$ & $47.2^{\mathrm{b}} \pm 4.49$ \\
\hline W & $0.13^{c} \pm 0.03$ & $1.97^{\mathrm{b}} \pm 0.24$ & $3.62^{\mathrm{a}} \pm 0.42$ & $2.63^{\mathrm{ab}} \pm 0.71$ \\
\hline $\mathrm{Zn}$ & $33.2^{\mathrm{d}} \pm 4.62$ & $63224^{\mathrm{a}} \pm 638$ & $28663^{c} \pm 1768$ & $43265^{\mathrm{b}} \pm 2014$ \\
\hline
\end{tabular}

a,b,c Means within rows with different letters differ significantly at $p \leq 0.05$ (Tukey's HSD test)

*Concentration in $\mathrm{g} \mathrm{kg}^{-1}$ 
mixture $\left(w_{\mathrm{m}}\right)$. This mixture was prepared from two mining wastes (Tables 1 and 2) blended in 1:1 (w/w) ratio using a POLYMIX PX-SR 90 D stirrer (KINEMATICA AG, Littau-Luzern, Switzerland). Individual plants were placed in cylindrical pots $(18 \times 19 \mathrm{~cm}$, diameter $\times$ height $)$ filled with $5.0 \mathrm{~kg}$ of waste mixture. As a control, the same tree species, diverse as regards their age, were planted in pots tiled with pure soil (c) collected from the Zielonka Forestry.

The 2-month experiment was conducted between March 31 and May 31, 2017, in an environment designed to show the response of the tested tree species under the influence of natural conditions (insolation, rainfall, wind). According to data presented by the Provincial Environmental Protection Inspectorate in Poznań, the mean concentration of $\mathrm{CO}_{2}$, $\mathrm{NO}, \mathrm{NO}_{2}, \mathrm{SO}_{2}$ and $\mathrm{O}_{3}$ and during the experiment was as follows $\left(\mu \mathrm{g} \mathrm{m}^{-3}\right)$ : 288; $10.1 ; 23.9 ; 4.0$; and 57 . The plants were watered with pure water on sunny days, while before rainfall the pots were covered with polypropylene lids to limit the amount of water and the risk of trees root decay and the rinsing of wastes from the pots.

\section{Elemental analysis of the organs of the tree species}

In the organs of the studied tree species, 67 elements have been analysed. For 27 of them (Au, Co, Cs, Dy, Er, Eu, Ga, Gd, Hf, Hg, Ir, La, Pd, Rb, Rh, Ru, Sb, Si, Sm, Sn, Tb, Te, $\mathrm{Th}, \mathrm{Ti}, \mathrm{Y}, \mathrm{Yb}$ and $\mathrm{Zr}$ ), the concentration of has been found below the limit of detection in all organs of both tree species. Additionally, the concentration of selected elements has been above the limit of detection in selected tree organs only (for Ho, Mo, Os, Re and Se). Finally, 36 detectable elements only are presented and described in this paper.
Table 2 Characteristics of organic matter, granulation and parameters of selected substrates originated from experimental areas

\begin{tabular}{|c|c|c|c|c|c|}
\hline Parameter & & Soil & Mining sludge & Flotation tailing & Waste mixture \\
\hline $\mathrm{pH}$ & & $7.22^{c} \pm 0.04$ & $7.76^{\mathrm{b}} \pm 0.10$ & $8.19^{a} \pm 0.03$ & $7.93^{\mathrm{b}} \pm 0.05$ \\
\hline $\mathrm{EC}\left(\mathrm{ds} \mathrm{m}^{-1}\right)$ & & $0.08^{\mathrm{d}} \pm 0.01$ & $5.42^{\mathrm{a}} \pm 0.02$ & $5.16^{\mathrm{c}} \pm 0.02$ & $5.27^{\mathrm{b}} \pm 0.04$ \\
\hline $\mathrm{Cl}^{-}$ & & $42.3^{\mathrm{d}} \pm 7.92$ & $5569^{a} \pm 51$ & $3627^{c} \pm 36.3$ & $4512^{\mathrm{b}} \pm 74.3$ \\
\hline $\mathrm{NO}_{3}^{-}$ & & $\mathrm{bDL}$ & $8.1^{\mathrm{c}} \pm 0.72$ & $13.8^{\mathrm{a}} \pm 1.01$ & $11.2^{\mathrm{b}} \pm 1.05$ \\
\hline $\mathrm{PO}_{4}^{3-}$ & & $27.6^{\mathrm{b}} \pm 16.3$ & $\mathrm{bDL}$ & $55.9^{\mathrm{a}} \pm 6.22$ & $26.8^{\mathrm{b}} \pm 4.58$ \\
\hline $\mathrm{SO}_{4}{ }^{2-}$ & & $80.3 \pm 5.4$ & $\mathrm{bDL}$ & $\mathrm{bDL}$ & $\mathrm{bDL}$ \\
\hline $\mathrm{NH}_{4}^{+}$ & & $2.71^{\mathrm{b}} \pm 1.01$ & $\mathrm{bDL}$ & $6.21^{\mathrm{a}} \pm 0.80$ & $3.05^{\mathrm{b}} \pm 0.41$ \\
\hline \multicolumn{6}{|c|}{ Granulation [\%] } \\
\hline$v \cos$ & $1<d<2$ & 5 & n.o & n.o & n.o \\
\hline $\cos$ & $0.5<d<1$ & 30 & n.o & n.o & n.o \\
\hline $\mathrm{ms}$ & $0.25<d<0.5$ & 26 & n.o & n.o & n.o \\
\hline fs & $0.1<d<0.25$ & 13 & n.o & n.o & n.o \\
\hline vfs & $0.05<d<0.1$ & 6 & 3 & 1 & 2 \\
\hline$\Sigma s$ & $0.05<d<2$ & 80 & 3 & 1 & 2 \\
\hline $\operatorname{cosi}$ & $0.02<d<0.05$ & 6 & 44 & 39 & 42 \\
\hline fsi & $0.006<d<0.02$ & 12 & 45 & 51 & 48 \\
\hline$\Sigma$ si & $0.02<d<0.05$ & 18 & 89 & 90 & 90 \\
\hline$\Sigma c$ & $d<0.002$ & 3 & 8 & 9 & 8 \\
\hline \multicolumn{6}{|c|}{ Organic matter $\left[\mathrm{g} \mathrm{kg}^{-1} \mathrm{DW}\right]$} \\
\hline SOC & & $12.1^{\mathrm{a}} \pm 1.2$ & $47.0^{\mathrm{d}} \pm 2.20$ & $18.7^{\mathrm{b}} \pm 0.60$ & $32.85^{\mathrm{c}} \pm 15.60$ \\
\hline $\mathrm{N}_{\mathrm{t}}$ & & $0.50^{\mathrm{a}} \pm 0.10$ & $1.40^{\mathrm{c}} \pm 0.20$ & $0.70^{\mathrm{a}} \pm 0.10$ & $1.03^{\mathrm{b}} \pm 0.39$ \\
\hline $\mathrm{SOC} / \mathrm{N}_{\mathrm{t}}$ & & $22.49^{\mathrm{a}} \pm 3.59$ & $34.30^{\mathrm{c}} \pm 3.21$ & $26.42^{\mathrm{ab}} \pm 2.75$ & $30.89^{\mathrm{bc}} \pm 5.36$ \\
\hline $\mathrm{C}_{\mathrm{HAs}}$ & & $4.55^{\mathrm{b}} \pm 0.50$ & $1.1^{\mathrm{a}} \pm 0.06$ & $1.3^{\mathrm{a}} \pm 0.10$ & $1.20^{\mathrm{a}} \pm 0.40$ \\
\hline$C_{\mathrm{FAs}}$ & & $4.15^{\mathrm{ab}} \pm 0.40$ & $5.0^{\mathrm{b}} \pm 0.60$ & $1.25^{\mathrm{c}} \pm 0.10$ & $3.13^{\mathrm{a}} \pm 2.12$ \\
\hline$C_{\mathrm{HAs}}: C_{\mathrm{FAs}}$ & & $1.10^{\mathrm{ab}} \pm 0.12$ & $0.24^{\mathrm{c}} \pm 0.17$ & $1.11^{\mathrm{b}} \pm 0.22$ & $0.62^{\mathrm{a}} \pm 0.45$ \\
\hline$C_{\text {Humins }}$ & & $3.40^{\mathrm{a}} \pm 0.70$ & $40.9^{\mathrm{d}} \pm 2.4$ & $16.15^{\mathrm{b}} \pm 0.60$ & $28.53^{c} \pm 13.67$ \\
\hline \multicolumn{6}{|c|}{ The contribution of humus fractions in SOC content [\%] } \\
\hline$C_{\mathrm{HAs}}$ & & 37.60 & 2.34 & 6.95 & 3.65 \\
\hline$C_{\mathrm{FAs}}$ & & 34.30 & 10.64 & 6.68 & 9.50 \\
\hline$C_{\text {Humins }}$ & & 28.10 & 87 & 86.36 & 86.85 \\
\hline
\end{tabular}

${ }^{\mathrm{a}, \mathrm{b}, \mathrm{c}}$ Means within rows with different letters differ significantly at $p \leq 0.05$ (Tukey's HSD test) 


\section{Sample preparation}

Plant materials collected were roots, stems and leaves of one- and two-year-old seedlings of T. cordata and twoyear-old seedlings of $U$. laevis. Due to the low survivability of seedlings of one-year-old $U$. laevis, these plants were not collected for analysis. The plants have been washed with deionised ultrapure water (Milli-Q, Millipore, Saint Luis, USA) to clean the samples (remove the remaining waste particles and possible element ions adsorbed at root systems). Leaves were also washed to remove ions transported from environmental dust. All the plants were weighed, divided into particular plant organs and weighed again to calculate the biomass of roots, stems and leaves. All of the samples have been dried in the electric oven (SLW 53 STD, Pol-Eko, Wodzisław Śląski, Poland) and then cut in Cutting Mill SM 200 (Retsch GmbH, Haan, Germany) to obtain a powder. Three representative samples of each organ of tree species (3 randomly selected from among the 6 cultivated plants) were weighed $(0.4000 \pm 0.0001 \mathrm{~g})$ and transported to $55 \mathrm{~mL}$ vials, where $8 \mathrm{~mL}$ of $65 \% \mathrm{HNO}_{3}$ (Sigma-Aldrich, St. Louis, MO, USA) was added. Digestion has been performed in the microwave mineralisation system CEM Mars6 (CEM, Matthews, NC, USA). After digestion the solutions have been filtered using paper filters (Qualitative Filter Papers Whatman, Grade 595: 4-7 $\mu \mathrm{m}$ ) and diluted with deionised water to a final volume of $50 \mathrm{~mL}$. Each of the samples was analysed in triplicate.

\section{Analysis of elements using inductively coupled plasma spectrometry}

The analysis has been performed with the use of the inductively coupled plasma spectrometer with optical emission detection (Agilent 5110 ICP-OES, Agilent, USA). The synchronous vertical dual view (SVDV) has been used for simultaneous axial and radial view of plasma. In the multielemental determination, the following common conditions were used: radio frequency (RF) power $1.2 \mathrm{~kW}$, nebulizer gas flow $0.7 \mathrm{~L} \mathrm{~min}^{-1}$, auxiliary gas flow $1.0 \mathrm{~L} \mathrm{~min}^{-1}$, plasma gas flow $12.0 \mathrm{~L} \mathrm{~min}^{-1}$, viewing height for radial plasma observation $8 \mathrm{~mm}$, detector CCD (charge-coupled device) temperature $-40^{\circ} \mathrm{C}$, signal accusation time $5 \mathrm{~s}$ for 3 replicates. The detection limits have been found at the level of $0.01 \mathrm{mg} \mathrm{kg}^{-1}$ dry weight (DW) for all elements determined (using 3-sigma criteria). The uncertainty has been estimated for the total analytical procedure (including sample preparation, $k=2$ ) at the level of $20 \%$. The traceability (recovery $80-120 \%$ ) for certified reference material analysis (CRM S-1-loess soil; CRM NCSDC (73349)—bush branches and leaves; CRM 2709—soil; CRM 405-estuarine sediments; CRM 667estuarine sediments) has been found acceptable for most the elements determined.

\section{Substrate analysis}

First, the soil samples were sieved through a 2-mm grid. A standard soil analysis was carried out to determine the granulometric fraction with the laser diffraction method using the Laser Particle Sizer ANALYSETTE 22 Fritsch. Soil reaction $(\mathrm{pH})$ and electrical conductivity (EC) (in a $1: 2.5$ soil-water suspension) were determined with a $\mathrm{pH}$ meter from Hanna Instruments HI 4221 and an EC meter from Hanna Instruments HI 2316, respectively. Soil organic carbon (SOC) was determined according to the dichromate wet oxidation method, and the total nitrogen concentration $(\mathrm{Nt})$ was determined with the Kjeldahl method. Humic substances (HS) - humic acids $\left(C_{\mathrm{HAs}}\right)$, fulvic acids $\left(C_{\mathrm{FAs}}\right)$ and humins $\left(C_{\text {Humins }}\right)$-in substrate samples were determined according to the method described by Kononowa (1968). The concentration of selected ions in the substrate samples was measured with ion chromatography (DIONEX 5000+) after $0.03 \mathrm{M}$ acetic acid extraction. The concentration of elements in the substrate samples was measured using an inductively coupled plasma spectrometer with optical emission detection after $\mathrm{HClO}_{4}$ digestion.

\section{Statistical analysis}

Obtained results were analysed using STATISTICA 12.0 software (StatSoft, USA). One way analysis of variance (ANOVA) followed by the post hoc Tukey's HSD test was applied to show the differences between the concentration of 36 elements in roots, stems and leaves of the tested plant species. Additionally, the same analysis was used to compare the biomass of these plants' biomass, both their particular organs and the whole plant biomass. Moreover, for graphical presentation of similarities and differences between specific plants, as regards their ability to phytoextract particular elements separately in their organs or the whole plant bodies, a heat map analysis was performed where two-dimensional variables (plant and element concentrations) were represented as blue colours. To show significant differences between the tested plants concerning the concentration of all 36 elements jointly in the whole their biomass, the Friedman rank sum test was used with pairwise comparisons using the Nemenyi multiple comparison tests (posthoc.friedman. nemenyi.test) with q approximation for unreplicated blocked data. Additionally, to show the potential of the analysed trees for the phytoextraction of all 36 elements jointly, the rank sum was performed. This analysis was performed using the agricolae package (R). 
To estimate the efficiency of element phytoextraction in the analysed tree species, bioconcentration factor (BCF) values were calculated as the ratio of the concentration of these elements in the harvested organs (leaves and stems) to their concentration in the substrate. Additionally, a translocation factor (TF) was calculated to show the ability of plants to transport elements from roots to aerial plant parts. TF values were calculated as the ratio of element concentration in the stem to their concentration in roots (Ali et al. 2013).

\section{Results and discussion}

\section{The significance of characteristics of substrates used in the experiment}

The characteristics of soil, waste mixture and both wastes (mining sludge and flotation tailing) are described in Tables 1 and 2 .

The soil consists mainly of sand particles $(80 \%)$, whereas particles with diameters in the range of $0.05-0.02$ corresponding to the silt fraction are dominant in mining sludge and flotation tailings (approx. 90\%), with a small admixture of other fractions. Due to the predominance of fine particles in the mining sludge and flotation tailings, the mixture of wastes used in the experiment was characterised by the predominance of a fine fraction as well. The soil was characterised by neutral $\mathrm{pH}=7.22$ and low salinity. In contrast, the mining sludge and flotation tailings were classified as saline, alkaline material. Similar properties were exhibited by the waste mixture (Richards 1954).

The SOC content in the soil was $12.1 \mathrm{~g} \mathrm{~kg}^{-1}$, which was significantly lower than the value of this parameter in the mining sludge, flotation tailings and waste mixture. Waste materials contaminated with heavy metals may contain organic pollutants, which largely influence the correct estimation of this parameter (Krumins et al. 2015). Additionally, the characterisation of organic matter in the mining sludge, flotation tailings and waste mixture revealed lower $C_{\mathrm{HAs}}$ content and a significantly higher $C_{\mathrm{Humins}}$ level than that in the soil. The $C_{\mathrm{FAs}}$ content was varied and was significantly lower in the flotation tailings than in the other materials. The concentration of $\mathrm{Nt}$ in the soil and flotation tailings was comparable, whereas the mining sludge exhibited a significantly higher concentration of this element; therefore, the mixture of wastes had a significantly higher content of this element than that noted in the pure soil. The significantly higher amount of SOC than that of $\mathrm{Nt}$ in the waste materials and their mixture yielded a significantly higher SOC/Nt ratio about the soil.

The concentration of the 36 analysed elements varied in the examined substrates. Significantly higher concentrations of these elements were generally recorded in the mining sludge and flotation tailings than in the soil, with a few exceptions. The content of $\mathrm{Al}, \mathrm{B}, \mathrm{Co}, \mathrm{K}$ and $\mathrm{Sc}$ in the soil was significantly higher only in comparison with the mining sludge; therefore, mixing of the waste resulted in significantly higher concentrations of all the elements in comparison with the soil. The concentration of the other elements in the soil was consistent with that noted for non-contaminated soils (Kabata-Pendias 2001). The mean concentrations of elements in the soil and the waste mixture were ranked in the following ranges: $>10,000,10,000-1000,1000-100$, $100-10,10-1$ and $<1 \mathrm{mg} \mathrm{kg}^{-1}$. In the soil, 10 out of the 36 elements ( $\mathrm{Ag}, \mathrm{Be}, \mathrm{Bi}, \mathrm{Ge}, \mathrm{Lu}, \mathrm{Pr}, \mathrm{Ta}, \mathrm{Tl}, \mathrm{Tm}$ and $\mathrm{V}$ ) were present below the limit of detection, 9 elements exhibited concentration values in the range of $10-1 \mathrm{mg} \mathrm{kg}^{-1}(\mathrm{Ni}, \mathrm{Cr}$, $\mathrm{Ba}, \mathrm{Sc}, \mathrm{Nd}, \mathrm{Co}, \mathrm{B}, \mathrm{Sr}, \mathrm{Ce}$ ), and 6 elements were present at a concentration $<1 \mathrm{mg} \mathrm{kg}^{-1}$, i.e. $\mathrm{Li}, \mathrm{As}, \mathrm{Cd}, \mathrm{W}$, In and Pt. The mean concentration of $\mathrm{K}, \mathrm{Al}, \mathrm{Mn}$ and $\mathrm{Na}$ in the soil was in the range of $1000-100 \mathrm{mg} \mathrm{kg}^{-1}$, and $\mathrm{Pb}, \mathrm{V}$ and $\mathrm{Cu}$ exhibited values from the range of $100-10 \mathrm{mg} \mathrm{kg}^{-1}$. $\mathrm{Ca}$ and $\mathrm{Mg}$ in the soil represented the range of $1000-10,000 \mathrm{mg} \mathrm{kg}^{-1}$, and $\mathrm{Fe}$ was the only element with a concentration $>10,000 \mathrm{mg} \mathrm{kg}^{-1}$. The largest number of elements in the waste mixture exhibited mean concentrations in the range of $100-10 \mathrm{mg} \mathrm{kg}^{-1}$ (Nd, Ce, V, B, Co, Pt, Li, Cd, Ag). Out of the 36 elements determined in the waste mixture, three ranges were represented by 6 elements each: $10,000-1000 \mathrm{mg} \mathrm{kg}^{-1}(\mathrm{~K}, \mathrm{Cu}$, $\mathrm{Pb}, \mathrm{Al}, \mathrm{As}, \mathrm{Mn}), 1000-100 \mathrm{mg} \mathrm{kg}^{-1}$ (Na, Sr, Ni, Tl, Cr, Ba) and $10-1 \mathrm{mg} \mathrm{kg}^{-1}$ (Ge, Sc, W, Ta, Tm, In). Lu, Be, Bi, Pr and $\mathrm{U}$ were present at a concentration $<1 \mathrm{mg} \mathrm{kg}^{-1}$, while $\mathrm{Ca}$, $\mathrm{Fe}$ and $\mathrm{Mg}$ represented the concentration $>10,000 \mathrm{mg} \mathrm{kg}^{-1}$.

The subject using trees in eco-technologies such as phytoremediation has been widely discussed in recent years, for example, by Baltrènaite et al. (2016), about their valuable traits. An example is T. cordata being described as a bioindicator (Aničić et al. 2011), which suggests that its capacity for efficient phytoextraction is strictly correlated with element concentration in soil. Unfortunately, the efficiency of element phytoextraction presented in this paper is a view of obtained results only and in other environmental conditions they could differ (Kosiba 2008), being related to the significant influence of soil physicochemical properties (Mleczek et al. 2009; Pinto et al. 2014; Tangahu et al. 2011). Physicochemical properties of soil such as particle size distribution, $\mathrm{pH}$, salinity or organic matter quality can significantly modify the uptake of individual elements, thereby affecting the effectiveness and efficiency of phytoextraction (Kabata-Pendias 2001; Sheoran et al. 2016). The soil used in the experiment did not show any contamination with the determined elements; nevertheless, its structure, dominated by coarse particles, may indicate unfavourable water conditions, as such soils cannot retain water and can, therefore, be too dry periodically. Additionally, due to the predominance of sandy fractions, the soil has a poorly developed 
sorption complex and does not accumulate not only contaminants but also compounds that are important for proper plant growth. Such soil is also poor in SOC and Nt because humic substances bind with finer particles forming stable complexes (Dziamski et al. 2005). The excessive predominance of carbon over $\mathrm{Nt}$ in the soil used in the experiment (SOC/Nt $>20: 1$ ) can reduce the intensity of mineralisation of organic compounds and lead to biological nitrogen sorption, which results in its lower availability to plants (Freitas et al. 2004). In turn, regarding $\mathrm{pH}$ and $\mathrm{EC}$, the soil was a non-saline neutral material, which is a favourable environment for the growth of most plants. In contrast to the soil, the waste mixture exhibited a fine particle size distribution, which may have influenced the air-water properties of this material, as development of plant roots is difficult in such conditions due to the impeded water and oxygen accessibility, which may have had a significant impact on the biomass of both tree species regardless of their age. Under oxygen deficiency, the nutrient and water uptake by plant roots is reduced, even when there are substantial amounts of these components in the substrate, and the plant may show symptoms of nutrient deficiency (Kasowska et al. 2017). Increased mobility of $\mathrm{Cd}, \mathrm{Cu}, \mathrm{Cr}$, and $\mathrm{Zn}$ is most frequently observed in lower soil oxygenation, whereas the solubility and mobility of $\mathrm{Cd}$ increase in conditions of increased oxygen availability (Kabata-Pendias 2001). Oxygen deficiency may result in secondary immobilisation of As, which may explain the absence of significant differences in the concentration of this element in both tree species (Krysiak and Karczewska 2011). Furthermore, the fine-grained structure of the material can influence the amounts of elements available to plants, thereby determining their uptake and accumulation in plants (Antoniadis et al. 2017; Kabata-Pendias 2004). An opposite correlation was observed between the release of $\mathrm{Cd}$ and the content of silt and clay fractions, which suggests the strong retention of this element in the finer soil fractions (Acosta et al. 2011). The structure of the waste mixture can additionally be determined by a high concentration of $\mathrm{Na}$, which has an impact, e.g. an increase in its swelling capacity or dispersion reduces its conductance and permeability (Telesiński 2012). The proper development of the 1-year-old and 2-year-old seedlings may have been influenced by the high $\mathrm{pH}$ and EC values in addition to the high contamination with almost all of the analysed elements. Given these parameters, this material was classified as alkaline and strongly saline; therefore, it created an unfavourable environment for the growth of most plants. The high salinity and alkaline reaction of the waste mixture were determined mainly by the alkaline elements $(\mathrm{Na}$ and $\mathrm{K})$ and $\mathrm{Cl}$ ions, whose level was substantially higher in the waste mixture than in the soil. A high concentration of these compounds can largely limit the uptake of biogenic nutrients by plants, e.g. $\mathrm{K}^{+}, \mathrm{Ca}^{2+}$ and $\mathrm{NO}_{3}{ }^{-}$(Nouri et al. 2017). Additionally, substrate salinity has a significant effect on the availability of water to plants. The potential of water is low in a strongly saline environment due to interactions of water with salt ions. In such conditions, plants have a limited capability of water uptake from the substrate, and osmotic stress results in inhibition of their growth (Munns 2002; Nouri et al. 2017). Some studies suggest that salinity can increase the mobility of some elements $(\mathrm{Cd}, \mathrm{Zn}, \mathrm{Pb}$ and $\mathrm{Cu})$, on the one hand (Filipović et al. 2018; Manousaki et al. 2008). On the other hand, mobility and bioavailability are determined by other factors, e.g. complexation with chlorides or competition with $\mathrm{Mg}$ and/or $\mathrm{Ca}$, and these elements were present at a very high level in the waste mixture; hence, the bioavailability of these elements to plants may be lower (Acosta et al. 2011). The soil $\mathrm{pH}$ determines not only the mobility and bioavailability of trace elements but also their uptake by plant roots (Kabata-Pendias 2001; Sheoran et al. 2016; Suda and Makino 2016). At alkaline reaction, the mobility of some elements declines; primarily the capability of $\mathrm{Ca}$ compounds to sorb these elements (Bolan et al. 2013). For instance, at $\mathrm{pH}>6.5 \mathrm{~Pb}$ is immobilised and is precipitated as carbonates and phosphates. Some elements, however, mainly those that form anionic forms in the soil solution (As, Mo, Se and Cr), can exhibit an increased solubility in the alkaline environment as well (Kabata-Pendias 2004). An increase in soil alkalinity is accompanied by a decrease in cadmium sorption, presumably due to displacement thereof from the sorption complex by cations of alkali metals, e.g. $\mathrm{Ca}^{2+}$ or $\mathrm{Mg}^{2+}$. At a pH value of approx. 8, Mn is mobilised mainly as anionic forms, which are available to plants as well (Kabata-Pendias 2001). Moreover, at the alkaline reaction, the availability of some plant nutrients, e.g. $\mathrm{Mg}$ and $\mathrm{P}$ as well as Fe and B, may be low, which further affects plant fitness and growth (Filipek and Skowrońska 2013). The content of organic matter in soils combined with other factors exerts a significant effect on the content and mobility of trace elements. Therefore, its role should also be considered for contaminated soils (Krumins et al. 2015). An organic matter deficit is often observed in highly contaminated soils (Antoniadis et al. 2017). Although the SOC content was significantly higher in the waste mixture used than in the soil, contamination with elements in such materials is often combined with organic contamination which impedes correct evaluation of the SOC content; therefore, the SOC content in the mining sludge, flotation tailing and waste mixture can be significantly overestimated (Krumins et al. 2015).

\section{Characteristics of tree seedling biomass}

The mean biomass of the control plants after the experiment was almost same for two-year-old $T$. cordata and $U$. laevis seedlings $(59.5 \pm 10.9$ and $57.0 \pm 12.7 \mathrm{~g}$, respectively) and significantly higher than one-year-old $T$. cordata 
Fig. 1 Characteristics of biomass $[\mathrm{g}]$ of tested tree organs after experiment

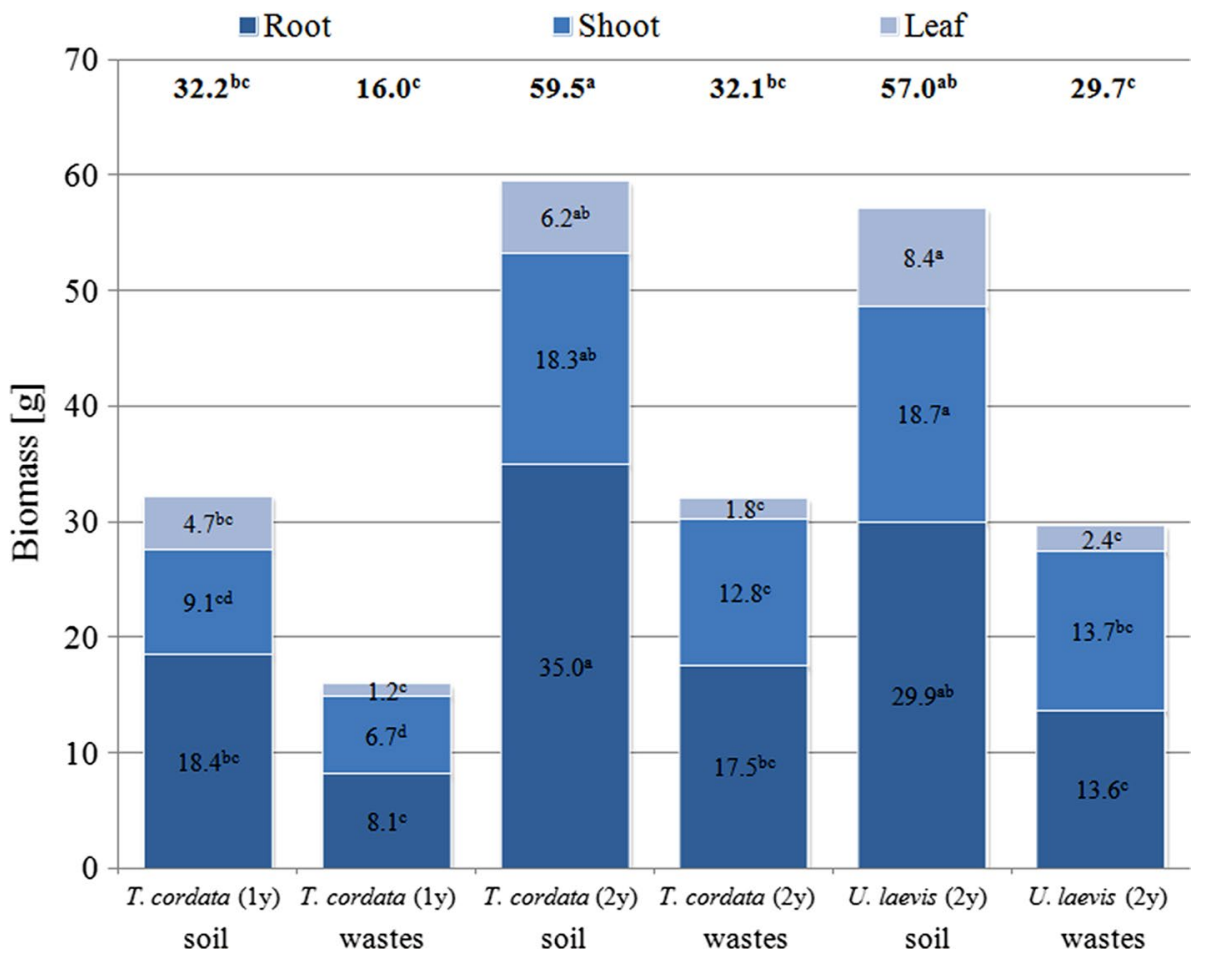

$(32.2 \pm 2.4 \mathrm{~g})$ (Fig. 1). In the case of plants growing on the waste mixture, a similar tendency was present, where the mean biomass of two-year-old $T$. cordata and $U$. laevis seedlings was $59.5 \pm 1.6$, and $57.0 \pm 8.6 \mathrm{~g}$, respectively, and the lowest mean biomass was recorded in one-year-old $T$. cor$\operatorname{data}(16.0 \pm 9.3 \mathrm{~g})$.

The mean decrease of the biomass of these 2 tree species (3 plants: two-year-old T. cordata, two-year-old U. laevis and one-year-old $T$, cordata) about control plants was: 50.5, 46.2 and $48 \%$, which pointed to the significant influence of high element concentration in the waste mixture. Two-yearold $T$. cordata and $U$. laevis were not significantly diverse as regards the biomass of particular organs in the whole total biomass of these species, both for the control and plants growing in the waste mixture.

\section{Element uptake and translocation}

Differences in element phytoextraction from contaminated substrates by plants (also trees) have previously been presented, for example, by Favas et al. (2014) and Mertens et al. (2007). Comparisons of particular trees have revealed differences between species but also genotypes (Pajević et al. 2016; Šijačić-Nikolić et al. 2012; Venturas et al. 2014). The characteristics of the concentration of 36 elements in the organs of the tested tree species are presented in Table $3 \mathrm{a}-c$. Generally, the concentration of these elements was higher in plants growing on waste mixture than in soil, with some exceptions. A significantly higher concentration of Ag was observed in the roots of two-year-old $T$. cordata growing in soil $\left(1.82 \pm 0.06 \mathrm{mg} \mathrm{kg}^{-1}\right)$ than in those growing on waste mixture $\left(0.98 \pm 0.25 \mathrm{mg} \mathrm{kg}^{-1}\right)$. A significantly higher concentration of $\mathrm{Ag}$ was also present in all the organs of 2-year-old $T$. cordata and $U$. laevis seedlings growing in soil compared to those in the waste mixture. This indicates a limitation in the accumulation of this metal from the highly polluted substrate. The same tendency was observed for Tm phytoextraction in older seedlings of both tree species and the leaves of 1-year-old T. cordata.

The concentration of elements was diverse about the kind of substrates where the plants were grown. Differences in concentration of elements were only observed between the particular tree organs of one-year-old $T$. cordata $(\mathrm{Al}, \mathrm{Be}$, Fe, Mn), two-year-old T. cordata (Be, In and $\mathrm{Mn}$ ) and twoyear-old $U$. laevis ( $\mathrm{Be}, \mathrm{K}, \mathrm{Na}, \mathrm{Nd}, \mathrm{Ni}$ and $\mathrm{Pb}$ ). For each of these three kinds of plants growing on the waste mixture, significant differences in element concentrations between their particular organs were observed for the following elements: Al, K, Mn, Na, Pb, Ta and Tl. Moreover, these differences were also present for other elements, dependent on the growing plant species and their age: B, Ce, Nd, Sc, Sr, $\mathrm{W}$ and $\mathrm{Zn}$ (one-year-old $T$. cordata), $\mathrm{Cu}, \mathrm{Li}$ and $\mathrm{Mg}$ (twoyear-old T. cordata), and B, Cu, Fe, Li, Mg, Pr, Pt, Si, Sr, U, $\mathrm{V}, \mathrm{W}$ and $\mathrm{Zn}$ (two-year-old $U$. laevis). The clear transport of elements from the root system to the leaves, revealed by their significantly higher concentration in leaf than in root for plants growing in soil, was observed for Mn (one- and two-year-old T. cordata) and K (two-year-old U. laevis) only. 
Table 3 The content of elements $\left[\mathrm{mg} \mathrm{kg}^{-1} \mathrm{DW}\right]$ in $T$. cordata and $U$. laevis leaves, stem and root, growing at soil $(c)$ and wastes mixture $\left(w_{\mathrm{m}}\right)$

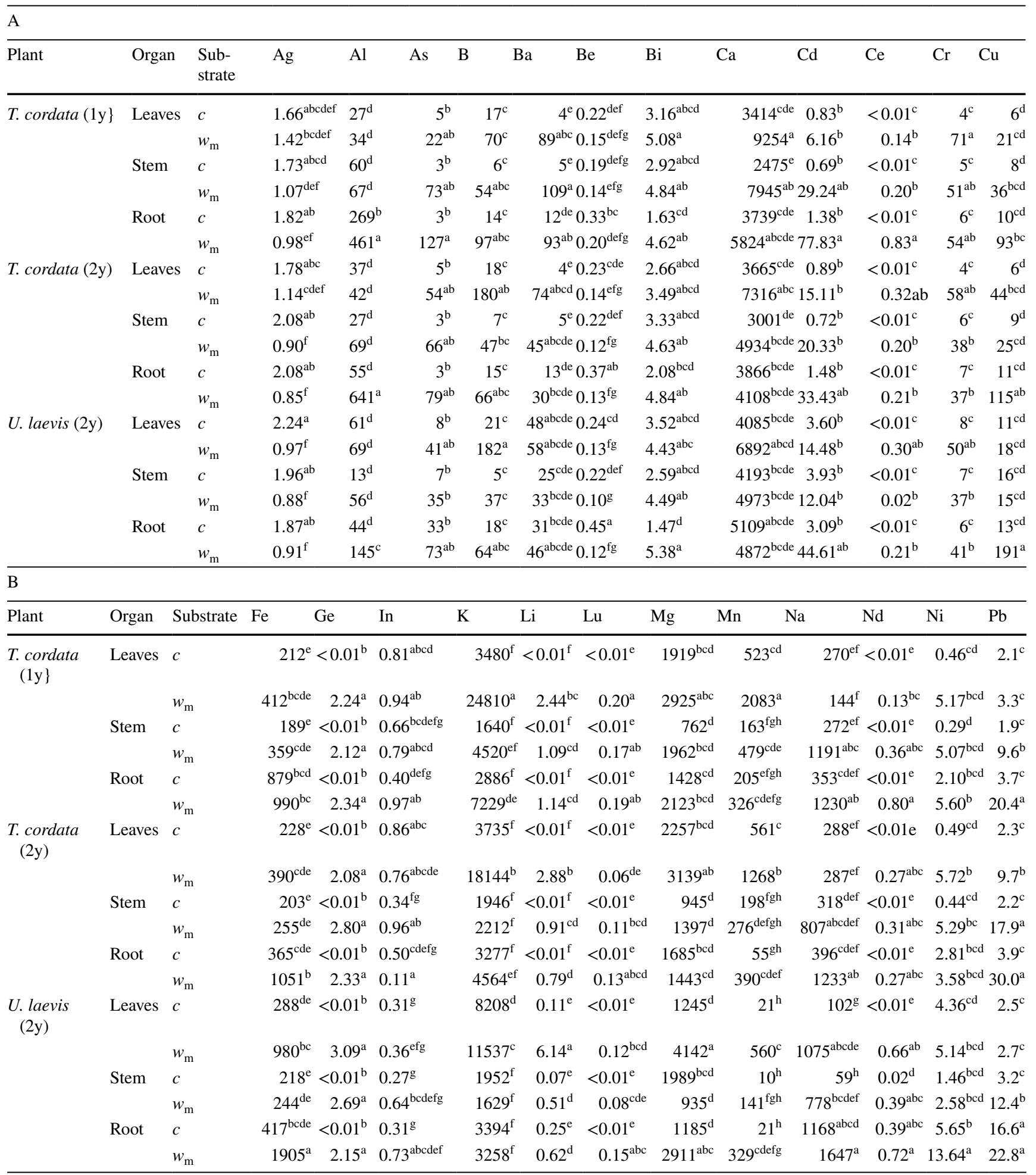


Table 3 (continued)

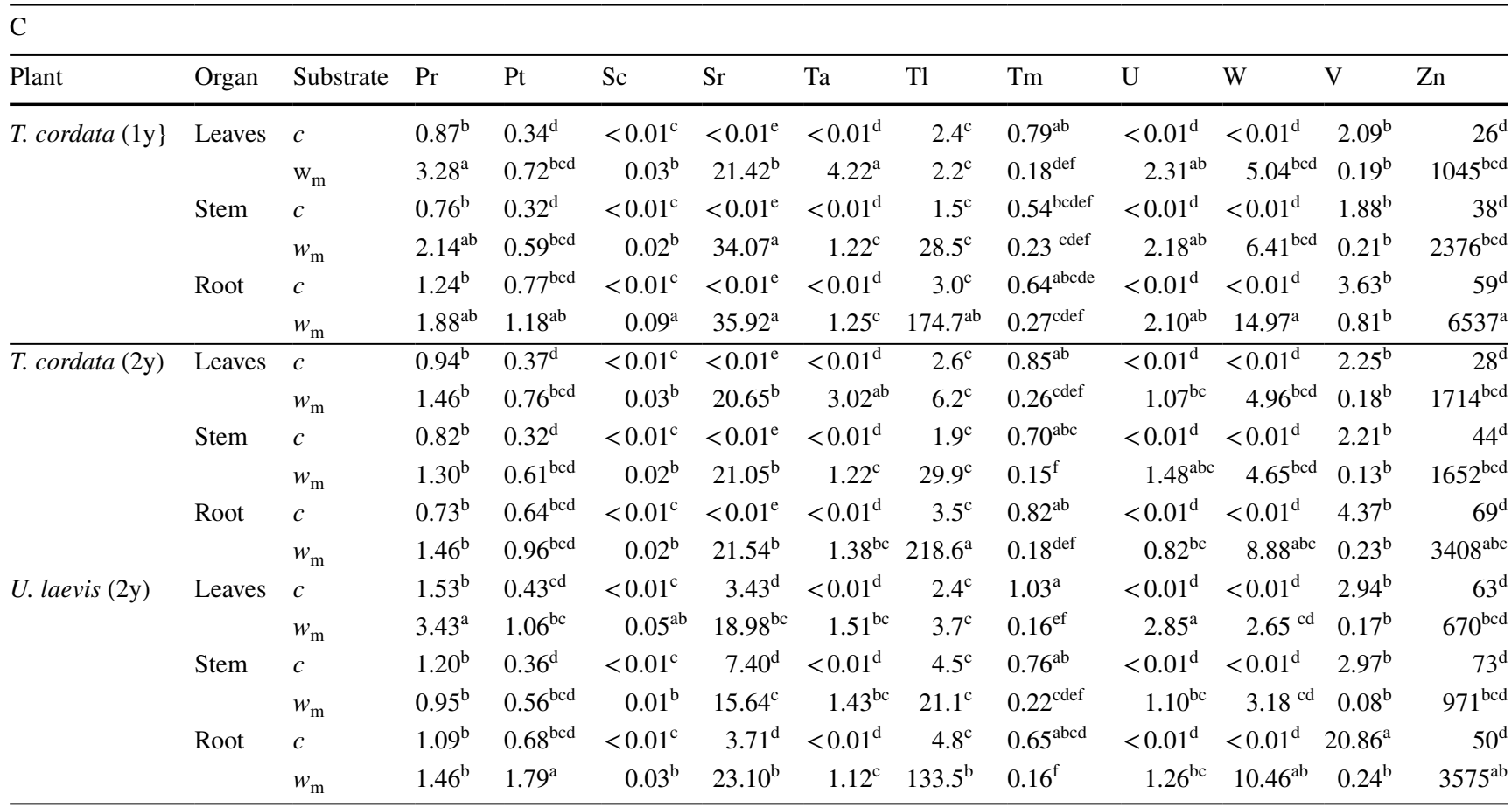

a,b,c Means within rows with different letters differ significantly at $p \leq 0.05$ (Tukey's HSD test)

In the case of seedlings planted on the waste mixture, the effective transport to leaves for $\mathrm{K}, \mathrm{Mn}$ and Ta (one-year-old T. cordata), K, Li, Mg and Mn (two-year-old T. cordata) and also $\mathrm{K}, \mathrm{Li}, \mathrm{Pr}$ and $\mathrm{U}$ (two-year-old $U$. laevis) was observed. Limited element phytoextraction, mainly to the root system, was determined for $\mathrm{Fe}$ (one-year-old $T$. cordata) and $\mathrm{Na}, \mathrm{Nd}$, $\mathrm{Ni}$ and $\mathrm{Pb}$ (two-year-old $U$. laevis) for plants growing in soil. In the case of plants growing in waste mixture, phytoextraction was mainly to roots for: $\mathrm{Al}, \mathrm{Ce}, \mathrm{Pb}, \mathrm{Tl}, \mathrm{W}$ and $\mathrm{Zn}$ (oneyear-old T. cordata), Al, Fe and Tl (two-year-old T. cordata) and also $\mathrm{Al}, \mathrm{Fe}, \mathrm{Ni}, \mathrm{Pb}, \mathrm{Pt}, \mathrm{Si}, \mathrm{Tl}, \mathrm{V}$ and $\mathrm{W}$ (two-year-old U. laevis). For a graphical presentation of the similarities/ differences in particular element phytoextraction in each of the three analysed tree organs, a heat map analysis was performed. The relationships obtained for element concentration calculated with and without an allowance of the biomass of particular organs are presented in Fig. 2a, b, respectively.

T. cordata and U. laevis analysed in this paper have been compared with other plants (Šomšák et al. 2000), but there are no data in the literature about a comparison of either of these tree species being of the same and different age, growing on such specific waste mixture. Efficient uptake of As, $\mathrm{B}, \mathrm{Ba}, \mathrm{Ca}, \mathrm{Cd}, \mathrm{Cr}, \mathrm{In}, \mathrm{K}, \mathrm{Mg}, \mathrm{Na}, \mathrm{Pt}$ and $\mathrm{Zn}$ confirmed by $\mathrm{BCF}$ values $>1$ was determined for all tree species growing in soil (Table 4).

Additionally, two-year-old $T$. cordata and $U$. laves were able to effectively accumulate $\mathrm{Cu}$, one- and two-year-old $T$. cordata $\mathrm{Mn}$, while two-year-old $U$. laves $\mathrm{Sr}$. In the case of plants growing on the waste mixture, $\mathrm{BCF}>1$ for $\mathrm{B}, \mathrm{Bi}$, $\mathrm{Cd}, \mathrm{K}, \mathrm{Na}, \mathrm{Pr}, \mathrm{Ta}, \mathrm{U}$ and $\mathrm{W}$ was determined for all tree species, while for one- and two-year-old T. cordata In and $\mathrm{Mn}$, one-year-old T. cordata - Ba and two-year-old U. laves Ge. Translocation factor (TF) values higher than 1 were determined for all elements except $\mathrm{Al}, \mathrm{As}, \mathrm{Ba}, \mathrm{Fe}, \mathrm{Ge}, \mathrm{Li}, \mathrm{Na}$ and $\mathrm{Nd}$ for all three studied plants (one- and two-year old) growing in soil. In the case of all tree seedlings planted on the waste mixture, $\mathrm{TF}>1$ for $\mathrm{Ag}, \mathrm{B}, \mathrm{Ba}, \mathrm{Be}, \mathrm{Bi}, \mathrm{Ca}, \mathrm{Cr}, \mathrm{Ge}$, In, $\mathrm{K}, \mathrm{Li}, \mathrm{Lu}, \mathrm{Mg}, \mathrm{Mn}, \mathrm{Pr}, \mathrm{Sr}, \mathrm{Ta}, \mathrm{Tm}$ and $\mathrm{U}$ was indicated.

It is worth underlining that both $\mathrm{BCF}$ and $\mathrm{TF}$ values higher than 1 for $\mathrm{B}, \mathrm{Bi}, \mathrm{K}, \mathrm{Pr}$, Ta and $\mathrm{U}$ were determined for one- and two-year-old seedlings of trees growing in soil and waste mixture. This shows the potential of the studied seedlings for the phytoextraction of these elements, regardless of the chemical characteristics of the substrate and plant age or species.

Besides the mixture of waste properties mentioned above, the nature of particular elements influences the absorption of elements by both tree species. For example, $\mathrm{Ag}, \mathrm{Li}$ and $\mathrm{B}$ are easily translocated from roots to aboveground parts of plants, whereas $\mathrm{Cd}, \mathrm{Co}, \mathrm{Cu}, \mathrm{Cr}$ and $\mathrm{Pb}$ accumulate in roots and are poorly transported to aboveground parts (Kabata-Pendias 2001). Modulation of tree responses may be associated with the presence of high concentrations of numerous elements, e.g. Fe. Venturas et al. (2014) characterised the phytoextraction of selected elements in $U$. laevis about the increased concentration of $\mathrm{Fe}$ in the 


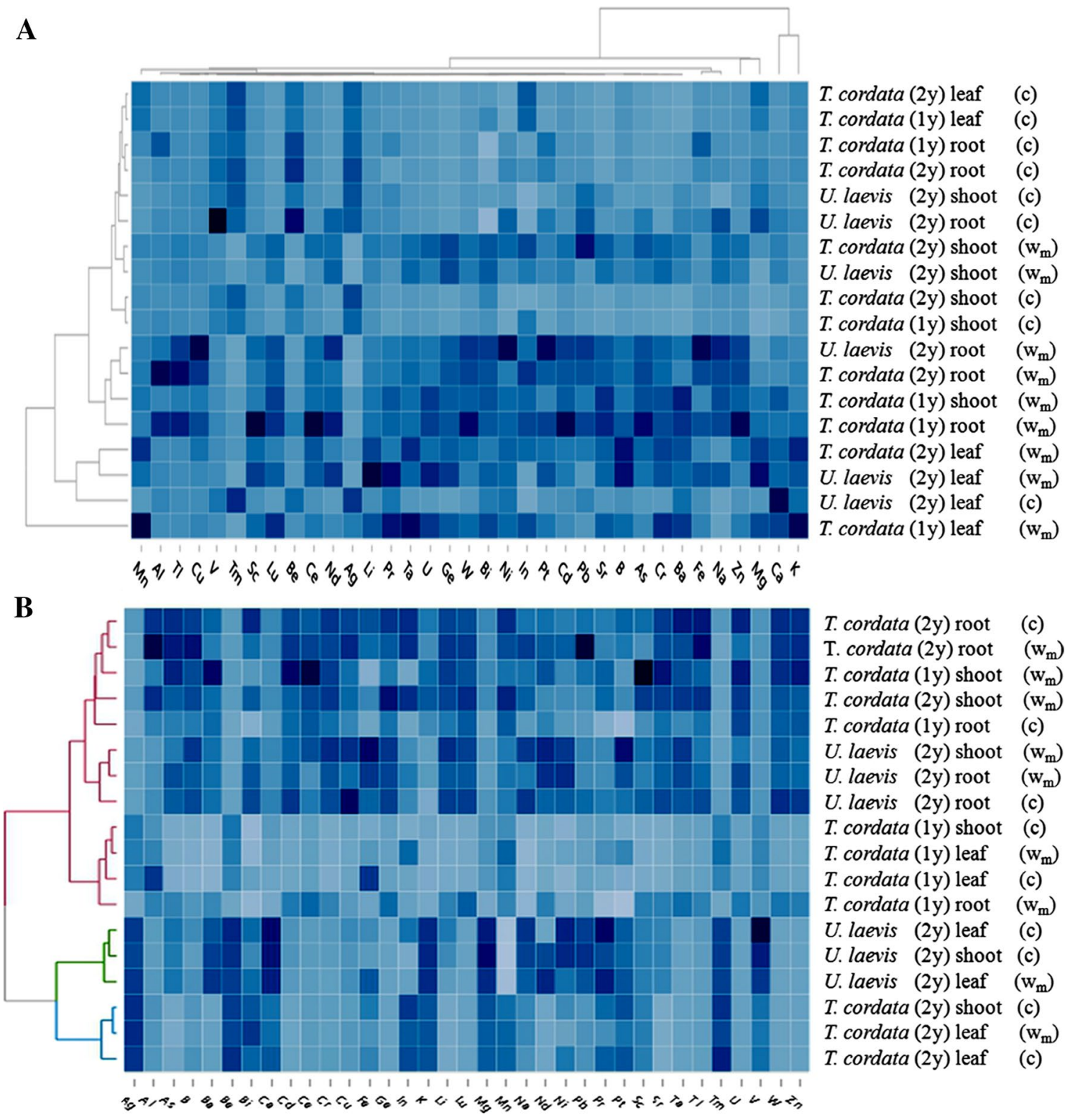

Fig. 2 Correlation between tested tree organs with regard to the concentration of particular elements (heat map) and presentation of a hierarchical tree plot for all studied plants

hydroponic solution. They noted a general increase in B, $\mathrm{Ca}, \mathrm{Cu}, \mathrm{Mg}, \mathrm{Mn}$ and $\mathrm{Zn}$ concentration in leaf and stem with the decrease in Fe concentration, whereas in our studies these relations were not ascertained. This suggests a strong and mutual influence of many other elements in the waste mixture as well as the significant role of a higher amount of elements in the waste mixture than in control soil (Makgalaka-Matlala et al. 2008). The relations between elements can also modify element translocation from roots to leaves, which confirms the results of Oroian et al. (2012), where the highest concentration of $\mathrm{Zn}$ and a low concentration of $\mathrm{Cd}$ and $\mathrm{Pb}$ were present in the leaves of $T$. cordata, whereas in our studies the same results were not observed for $\mathrm{Zn}$ in leaves. It is worth emphasising that elements present in organs are not transported from substrates only but also from the air, which for Tilia spp. confirms the results described by Serbula et al. (2013).

\section{Content of elements in whole tree seedling biomass}

Analysis of element contents in the whole biomass of tested plants (Table 5) has generally shown differences and relationships presented previously. A higher content of $\mathrm{Ag}, \mathrm{Be}$, $\mathrm{Bi}, \mathrm{In}, \mathrm{Tm}$ and $\mathrm{V}$ was observed in plants growing in the waste mixture than observed in control plants. The opposite situation was found for $\mathrm{As}, \mathrm{B}, \mathrm{Cd}, \mathrm{Ce}, \mathrm{Cr}, \mathrm{Ge}, \mathrm{Li}, \mathrm{Lu}, \mathrm{Mn}$, 
Table 4 Bioconcentration and translocation factor values

\begin{tabular}{|c|c|c|c|c|c|c|c|c|c|c|c|c|c|c|c|c|c|c|c|}
\hline Plant & Substrate & Index & $\mathrm{Ag}$ & $\mathrm{Al}$ & As & B & $\mathrm{Ba}$ & $\mathrm{Be}$ & $\mathrm{Bi} \quad \mathrm{C}$ & $\mathrm{Ca} \mathrm{Cd}$ & $\mathrm{Ce}$ & $\mathrm{Cr}$ & $\mathrm{Cu}$ & $\mathrm{Fe}$ & $\mathrm{Ge}$ & In & $\mathrm{K}$ & $\mathrm{Li}$ & $\mathrm{Lu}$ \\
\hline \multirow[t]{4}{*}{ T. cordata (1y) } & \multirow[t]{2}{*}{$c$} & $\mathrm{BCF}$ & - & 0.19 & 42.0 & 14.8 & 1.5 & - & - & $1.9 \quad 8.4$ & 0.02 & 1.24 & 0.94 & 0.04 & - & 12.2 & 7.8 & 0.07 & - \\
\hline & & $\mathrm{TF}$ & 1.9 & 0.3 & 2.3 & 1.6 & 0.7 & 1.2 & $3.7 \quad 1$ & $1.6 \quad 1.1$ & 2.0 & 1.5 & 1.3 & 0.5 & 2.0 & 3.7 & 1.8 & 2.0 & 2,0 \\
\hline & \multirow[t]{2}{*}{$w_{\mathrm{m}}$} & $\mathrm{BCF}$ & 0.19 & 0.04 & 0.00 & 5.2 & 1.5 & 0.56 & 220 & $0.1 \quad 2.4$ & 0.01 & 0.78 & 0.02 & 0.03 & 0.76 & 1.4 & 7.4 & 0.20 & 0,67 \\
\hline & & $\mathrm{TF}$ & 2.5 & 0.2 & 0.8 & 1.3 & 2.1 & 1.4 & 2.13 & $\begin{array}{ll}3.0 & 0.5\end{array}$ & 0.4 & 2.3 & 0.6 & 0.8 & 1.9 & 1.8 & 4.1 & 3.1 & 2,0 \\
\hline \multirow[t]{4}{*}{ T. cordata $(2 \mathrm{y})$} & \multirow[t]{2}{*}{$c$} & $\mathrm{BCF}$ & - & 0.14 & 43.0 & 16.6 & 1.6 & - & - & $2.2 \quad 9.0$ & 0.02 & 1.42 & 1.04 & 0.04 & - & 10.0 & 8.6 & 0.07 & - \\
\hline & & $\mathrm{TF}$ & 1.9 & 1.2 & 2.4 & 1.7 & 0.8 & 1.3 & 2.91 & $\begin{array}{ll}1.7 & 1.1\end{array}$ & 2.0 & 1.5 & 1.4 & 1.2 & 2.0 & 2.4 & 1.7 & 2.0 & 2,0 \\
\hline & \multirow[t]{2}{*}{$w_{\mathrm{m}}$} & $\mathrm{BCF}$ & 0.15 & 0.05 & 0.01 & 9.5 & 0.9 & 0.51 & 180 & $0.1 \quad 2.4$ & 0.01 & 0.61 & 0.02 & 0.02 & 0.85 & 1.3 & 5.1 & 0.21 & 0,31 \\
\hline & & $\mathrm{TF}$ & 2.4 & 0.2 & 1.5 & 3.4 & 4.0 & 2.1 & 1.73 & $3.0 \quad 1.1$ & 2.4 & 2.6 & 0.6 & 0.6 & 2.1 & 1.6 & 4.5 & 4.8 & 1,3 \\
\hline \multirow[t]{4}{*}{ U. laevis $(2 \mathrm{y})$} & \multirow[t]{2}{*}{$c$} & $\mathrm{BCF}$ & - & 0.18 & 81.6 & 17.3 & 12.3 & - & - & $6.0 \quad 41.9$ & 0.02 & 2.02 & 1.95 & 0.05 & - & 4.8 & 15.5 & 0.64 & - \\
\hline & & $\mathrm{TF}$ & 2.2 & 1.9 & 0.4 & 1.4 & 2.4 & 1.0 & 4.13 & $3.6 \quad 2.4$ & 2.0 & 2.4 & 2.1 & 1.2 & 2.0 & 1.9 & 3.0 & 0.7 & 2,0 \\
\hline & \multirow[t]{2}{*}{$w_{\mathrm{m}}$} & $\mathrm{BCF}$ & 0.14 & 0.05 & 0.00 & 9.2 & 0.7 & 0.45 & 190 & $0.1 \quad 1.8$ & 0.01 & 0.55 & 0.01 & 0.05 & 1.01 & 0.8 & 3.3 & 0.37 & 0,35 \\
\hline & & $\mathrm{TF}$ & 2.0 & 0.8 & 1.0 & 3.4 & 2.0 & 1.9 & 1.72 & $2.4 \quad 0.6$ & 1.5 & 2.1 & 0.2 & 0.6 & 2.7 & 1.4 & 4.0 & 10.8 & 1,3 \\
\hline Plant & Substrate & Index & $\mathrm{Mg}$ & $\mathrm{Mn}$ & $\mathrm{Na}$ & $\mathrm{Nd}$ & $\mathrm{Ni}$ & $\mathrm{Pb}$ & $\operatorname{Pr}$ & $\mathrm{Pt}$ & $\mathrm{Sc}$ & $\mathrm{Sr}$ & Та & $\mathrm{Tl}$ & $\mathrm{Tm}$ & $\mathrm{U}$ & V & W & $\mathrm{Zn}$ \\
\hline \multirow[t]{4}{*}{ T. cordata $(1 \mathrm{y})$} & \multirow[t]{2}{*}{$c$} & $\mathrm{BCF}$ & 2.3 & 3.9 & 4.9 & 0.01 & 0.09 & 0.11 & - & 16.6 & 0.00 & 0.02 & - & - & - & - & 0.15 & 0.2 & 1.93 \\
\hline & & $\mathrm{TF}$ & 1.9 & 3.3 & 1.5 & 2.0 & 0.4 & 1.1 & 1.3 & 0.9 & 2.0 & 2.0 & 2.0 & 1.3 & 2.1 & 2.0 & 1.1 & 2.0 & 1.1 \\
\hline & \multirow[t]{2}{*}{$w_{\mathrm{m}}$} & $\mathrm{BCF}$ & 0.2 & 2.9 & 1.6 & 0.01 & 0.04 & 0.00 & 13.9 & 0.1 & $0.01 \quad$ & $0.18 \quad 2$ & 2.22 & 0.13 & 0.27 & 40.86 & 0.01 & 4.4 & 0.08 \\
\hline & & $\mathrm{TF}$ & 2.3 & 7.9 & 1.1 & 0.6 & 1.8 & 0.6 & 2.9 & 1.1 & 0.7 & 1.5 & 4.4 & 0.2 & 1.5 & 2.1 & 0.5 & 0.8 & 0.5 \\
\hline \multirow[t]{4}{*}{ T. cordata $(2 \mathrm{y})$} & \multirow[t]{2}{*}{$c$} & $\mathrm{BCF}$ & 2.8 & 4.3 & 5.5 & 0.01 & 0.09 & 0.12 & - & 17.2 & $0.00 \quad \mathrm{C}$ & 0.02 & - & - & - & - & 0.17 & 0.2 & 2.17 \\
\hline & & $\mathrm{TF}$ & 1.9 & 13.8 & 1.5 & 2.0 & 0.3 & 1.1 & 2.4 & 1.1 & 2.0 & 2.0 & 2.0 & 1.3 & 1.9 & 2.0 & 1.0 & 2.0 & 1.0 \\
\hline & \multirow[t]{2}{*}{$w_{\mathrm{m}}$} & $\mathrm{BCF}$ & 0.2 & 1.8 & 1.3 & 0.01 & 0.04 & 0.01 & 7.06 & 0.1 & 0.01 & 0.14 & 1.73 & 0.15 & 0.27 & 23.19 & 0.01 & 3.7 & 0.08 \\
\hline & & $\mathrm{TF}$ & 3.1 & 4.0 & 0.9 & 1.8 & 3.1 & 2.2 & 1.9 & 1.4 & 2.1 & 1.9 & 3.1 & 0.2 & 2.3 & 3.1 & 1.3 & 1.1 & 1.0 \\
\hline \multirow[t]{4}{*}{ U. laevis $(2 \mathrm{y})$} & \multirow[t]{2}{*}{$c$} & $\mathrm{BCF}$ & 2.8 & 0.2 & 1.5 & 0.01 & 0.67 & 0.54 & - & 19.7 & 0.00 & 8.20 & - & - & - & - & 0.22 & 0.2 & 4.10 \\
\hline & & $\mathrm{TF}$ & 1.1 & 1.4 & 0.1 & 0.1 & 1.0 & 1.2 & 2.5 & 1.2 & 2.0 & 2.9 & 2.0 & 1.5 & 2.8 & 2.0 & 0.3 & 2.0 & 2.7 \\
\hline & \multirow[t]{2}{*}{$w_{\mathrm{m}}$} & $\mathrm{BCF}$ & 0.2 & 0.8 & 2.2 & 0.01 & 0.03 & 0.00 & 11.24 & 0.1 & 0.01 & 0.11 & 1.20 & 0.10 & 0.25 & 32.63 & 0.01 & 2.2 & 0.04 \\
\hline & & $\mathrm{TF}$ & 4.3 & 2.1 & 1.1 & 1.5 & 0.6 & 0.3 & 3.0 & 0.9 & 1.9 & 1.5 & 2.6 & 0.2 & 2.4 & 4.3 & 1.1 & 0.6 & 0.5 \\
\hline
\end{tabular}

$\mathrm{Na}, \mathrm{Nd}, \mathrm{Sr}, \mathrm{Ta}, \mathrm{Tl}, \mathrm{U}, \mathrm{W}$ and $\mathrm{Zn}$. For the remaining elements, their phytoextraction was diverse which was probably related to their similar accumulation from soil and waste mixture or differences in their translocation at the vertical section of particular plants. The graphical presentation of these relationships was also characterised by the heat map (Fig. 3).

According to the Friedman rank sum test with pairwise comparisons using Nemenyi multiple comparison tests, significant differences between particular trees growing on soil and waste mixture were determined. In the case of trees growing on the soil, there was a significant difference (Friedman Chi-squared $=45.825, \mathrm{df}=2, p$ value $=1.12 \mathrm{e}^{-10}$ ) between $T$. cordata (1y) and U. laevis (2y) only, as regards their ability to phytoextract elements. The obtained results have shown that the most effective accumulators of these elements were seedlings of two-year-old $U$. laevis. For trees growing on the waste mixture, significant differences were observed between all pairs of trees (Friedman Chisquared $=27.838, d f=2, p$ value $\left.=9.016 \mathrm{e}^{-07}\right)$. According to the rank sum, the ability to phytoextract 36 elements jointly was as follows: two-year-old $T$. cordata $>$ two-year-old $U$. laevis $>$ one-year-old T. cordata.

Comparison of our results with other data described in numerous papers is difficult because there are few data on the concentration of many of the elements in the studied tree species; it is limited to some elements only (Cekstere and Osvalde 2013) or for other varieties than studied in our paper (Bergqvist and Greger 2012). The studied tree species could be promising as regards their structural components, easy adaptation and biomass. In the case of the latter, neither species are characterised with the same fast growth as 


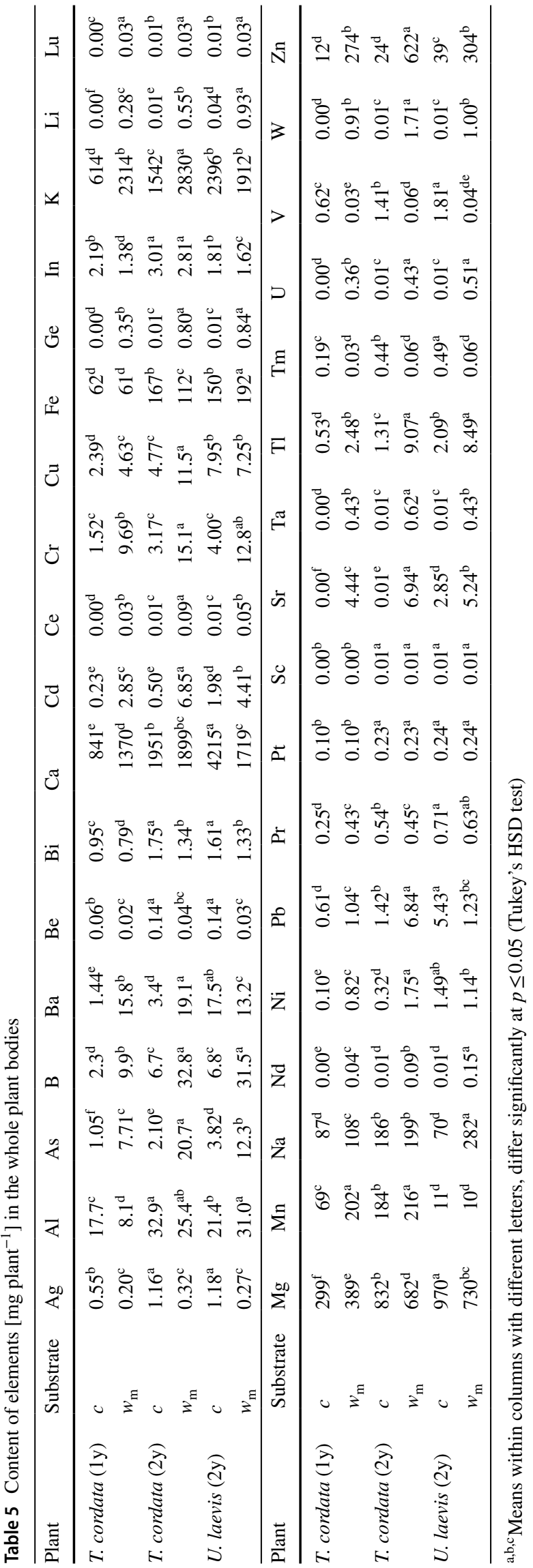

selected tree or bush species (Krzyżaniak et al. 2015), but higher biomass than known hyperaccumulators allows them to collect quite a great amount of accumulated elements (Keller and Hammer, 2005). In our previous study (Mleczek et al. 2016), we have compared both these tree species (twoyear-old seedlings), growing on extremely polluted sludge, where $U$. laevis was characterised by significantly higher phytoextraction of As in its stems than the same organ of T. cordata. In the present paper, the concentration of As in both tree species was not significantly different. The fact that the plants were collected from the same place, but the waste mixture was different suggests that the above signalised the significant role of substrate and its chemical composition on plant response. The same relationships were observed for $\mathrm{Cd}, \mathrm{Cu}$ and $\mathrm{Pb}$.

The waste mixture used in the experiment was watered and not dried to increase its dusting, although transport of elements directly to tree leaves was possible, especially in the case of $T$. cordata, similarly to the results obtained by Soudek et al. (2012). Of course, our leaves were washed, but what may have occurred before the end of the experiment and how many elements had been transported to leaves? This could explain why the two-year-old T. cordata was more effective in phytoextraction of all elements jointly than two-year-old U. laevis (Alagić et al. 2013). It also suggests the need for subsequent studies to compare plants of different ages concerning their ability to phytoextract elements in leaves, which would explain the real significance of this organ regarding its phytoextraction efficiency between oneand two-year-old seedlings of T. cordata (Kosiba 2008).

\section{Conclusion}

Phytoremediation is a viable biological method for the remediation of areas polluted with especially toxic elements. The waste mixture used in the experiment was characterised by a high concentration of selected elements, which undoubtedly influenced plant response (biomass crop) but particularly element phytoextraction. The selection of tree species and studies related to this is difficult as the vegetation of these plants occurs only once a year. Moreover, due to their slow growth, it is necessary to conduct studies over many years to answer some fundamental questions. We have shown the initial response of $T$. cordata and U. laevis seedlings as representatives of two valuable tree species able to adapt to extremely unfavourable conditions. The obtained results unambiguously indicated that 1-year-old seedlings of $U$. laevis have only limited practical use in phytoremediation, whereas 2-year-old trees are diverse as regards their ability to phytoextract elements. These observations suggest that subsequent studies should aim to verify older specimens of these tree species regarding phytoextraction of elements. Concerning practical 


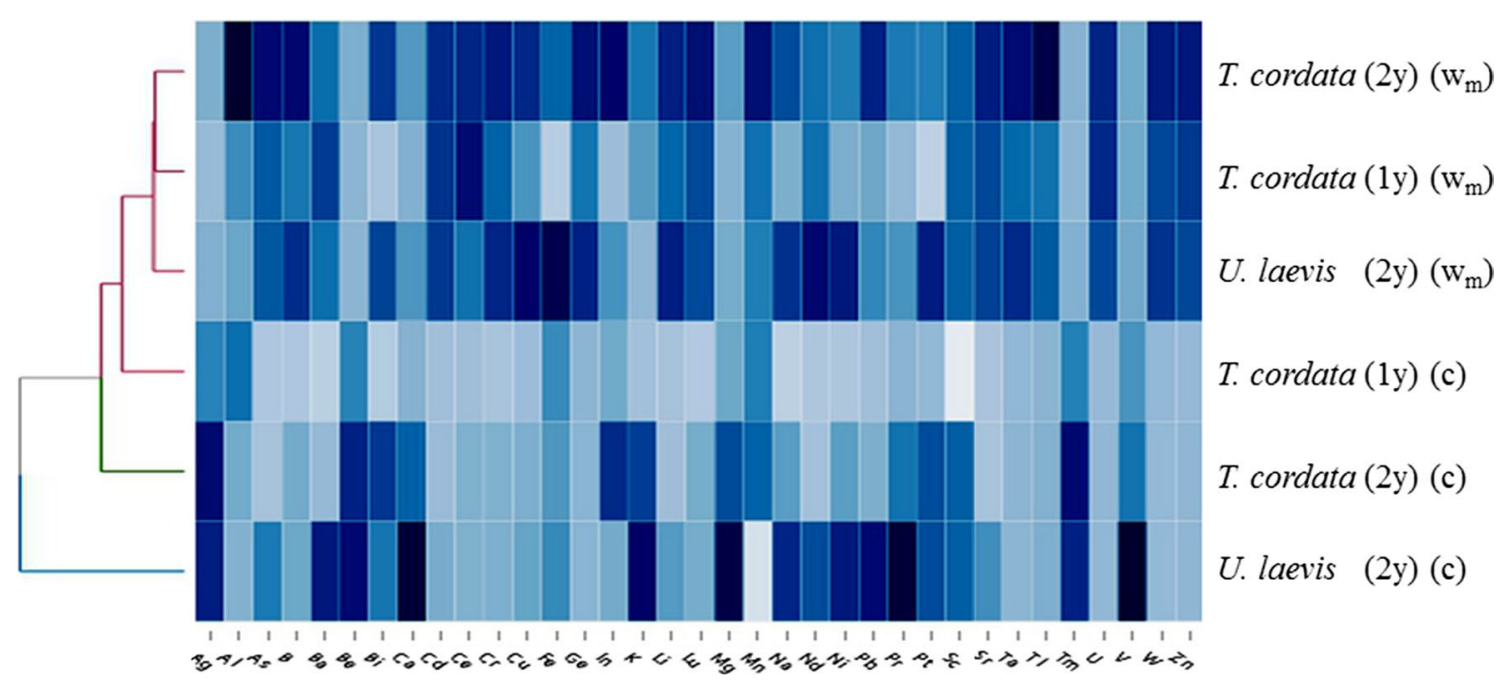

Fig. 3 Correlation between tested tree organs with regard to the concentration of particular elements (heat map) and presentation of a hierarchical tree plot for mean values for all studied plants

aspects (plant size), three-year-old seedlings are likely to be most suitable for practical application in effective phytoextraction of inorganic pollutants from post-mining areas.

From a practical point of view, the worse results of oneyear-old in comparison with two-year-old Tilia cordata indicate that a greater opportunity exists to use this species for afforestation on flotation tailings and sewage sludge if it is introduced by man, than the possibility of natural regeneration of trees on such deposits, because by artificial afforestation we can introduce two-year-old plants, but in natural regeneration the tree must pass through the more vulnerable phase of one-year-old seedlings. This could explain the lack of natural regeneration of these types of sediments.

Acknowledgement This study is financially supported by the National Science Centre of Poland under Grant Code Opus 2014/15/B/ NZ9/02172 for Piotr Goliński. The Authors would also like to thank the staff of the Turek Forest Division for delivery of experimental materials.

\section{Compliance with ethical standards}

Conflict of interest The authors declare that they have no conflict of interest.

Ethical approval This article does not contain any studies with human participants or animals performed by any of the authors.

Open Access This article is distributed under the terms of the Creative Commons Attribution 4.0 International License (http://creativeco mmons.org/licenses/by/4.0/), which permits unrestricted use, distribution, and reproduction in any medium, provided you give appropriate credit to the original author(s) and the source, provide a link to the Creative Commons license, and indicate if changes were made.

\section{References}

Acosta JA, Jansen B, Kalbitz K, Faz A, Martinez-Martinez S (2011) Salinity increases mobility of heavy metals in soils. Chemosphere 85:1318-1324. https://doi.org/10.1016/j.chemospher e.2011.07.046

Alagić SČ, Šerbul SS, Tošić SB, Pavlović AN, Petrović JV (2013) Bioaccumulation of arsenic and cadmium in birch and lime from the Bor region. Arch Environ Contam Toxicol 65:671-682. https ://doi.org/10.1007/s00244-013-9948-7

Ali H, Khan E, Anwar SM (2013) Phytoremediation of heavy metals - concepts and applications. Chemosphere 91:869-881. https ://doi.org/10.1016/j.chemosphere.2013.01.075

Aničić M, Spasić T, Tomašević M, Rajšić S, Tasić M (2011) Trace elements accumulation and temporal trends in leaves of urban deciduous trees (Aesculus hippocastanum and Tilia spp.). Ecol Indic 11:824-830. https://doi.org/10.1016/j.ecolind.2010.10.009

Antoniadis V, Levizou E, Shaheen SM, Sik Ok Y, Sebastian A, Baum Ch, Prasad MNV, Wenzel WW, Rinklebe J (2017) Trace elements in the soil-plant interface: phytoavailability, translocation, and phytoremediation-a review. Earth Sci Rev 171:621-645. https ://doi.org/10.1016/j.earscirev.2017.06.005

Baltrėnaitė E, Baltrėnas PA, Lietuvninkas A (2016) The sustainable role of the tree in environmental protection. Springer, Basel

Bergqvist C, Greger M (2012) Arsenic accumulation and speciation in plants from different habitats. Appl Geochem 27:615-622. https ://doi.org/10.1016/j.apgeochem.2011.12.009

Bolan N, Mahimairaja S, Kunhikrishnan A, Choppala G (2013) Phosphorus-arsenic interactions in variable-charge soils in reaction to arsenic mobility and bioavailability. Sci Total Environ 463464:1154-1162. https://doi.org/10.1016/j.scitotenv.2013.04.016

Brunner I, Luster J, Günthardt-Goerg MS, Frey B (2008) Heavy metal accumulation and phytostabilisation potential of tree fine roots in a contaminated soil. Environ Pollut 152:559-568. https://doi. org/10.1016/j.envpol.2007.07.006

Budzyńska S, Krzesłowska M, Niedzielski P, Goliński P, Mleczek M (2017) Arsenite phytoextraction and its influence on selected nutritional elements in one-year-old tree species. Microchem J 133:530-538. https://doi.org/10.1016/j.microc.2017.04.022 
Cekstere G, Osvalde A (2013) A study of chemical characteristic of soil in relations to street trees status in Riga (Latvia). Urban For Urban GRE 12:69-78. https://doi.org/10.1016/j.ufug.2012.09.004

Chen B, Zhang Y, Rafiq MT, Khan KY, Pan F, Yang X, Feng Y (2014) Improvement of cadmium uptake and accumulation in Sedum alfredii by endophytic bacteria Sphingomonas SaMR12: effects on plant growth and root exudates. Chemosphere 117:367-373. https://doi.org/10.1016/j.chemosphere.2014.07.078

Dziamski A, Gonet SS, Debska B (2005) Properties of humus in reaction to soil particle size fraction. Sci Pap Univ Lativia 692:29-37

Erdemir ÜS, Arslan H, Güleryüz G, Güçer S (2016) Elemental composition of plant species from an abandoned tungsten mining area: are they useful for biogeochemical exploration and/or phytoremediation purposes? Bull Environ Contam Toxicol 98:299-303. https://doi.org/10.1007/s00128-016-1899-Z

Favas PJC, Pratas J, Varun M, D'Souza R, Paul MS (2014) Phytoremediation of soils contaminated with metals and metalloids at mining areas: potential of native flora. In: Hernandez-Soriano MC (ed) Environmental risk assessment of soil contamination. InTech Publisher, Chennai, pp 485-517

Filipek T, Skowrońska M (2013) Current dominant causes and effects of acidification of soils under agricultural use in Poland. Acta Agrophys 20:283-294 (in Polish)

Filipović L, Romić M, Romić D, Filipović V, Ondrašek G (2018) Organic matter and salinity modify cadmium soil (phyto) availability. Ecotoxicol Environ Saf 147:824-831. https://doi. org/10.1016/j.ecoenv.2017.09.041

Freitas H, Prasad MNV, Pratas J (2004) Plant community tolerant to trace elements growing on the degraded soils of Sao Domingos mine in the south east of Portugal: environmental implications. Environ Int 30:65-72. https://doi.org/10.1016/S0160 $-4120(03) 00149-1$

Goliński P, Mleczek M, Magdziak Z, Gąsecka M, Borowiak K, Dąbrowski J, Kaczmarek Z, Rutkowski P (2015) Efficiency of $\mathrm{Zn}$ phytoextraction, biomass yield and formation of low-molecular-weight organic acids in $S \times$ rubens - a hydroponic experiment. Chem Ecol 31:345-364. https://doi.org/10.1080/02757 540.2014 .993976

Hassinen V, Vallinkoski V-M, Issakainen S, Tervahauta A, Kärenlampi S, Servomaa K (2009) Correlation of foliar MT2b expression with $\mathrm{Cd}$ and $\mathrm{Zn}$ concentrations in hybrid aspen (Populus tremula $\times$ tremuloides) grown in contaminated soil. Environ Pollut 157:922-930. https://doi.org/10.1016/j.envpol.2008.10.023

Järup L (2003) Hazards of heavy metal contamination. Brit Med Bull 68:167-182. https://doi.org/10.1093/bmb/ldg032

Kabata-Pendias A (2001) Trace elements in soils and plants, 3rd edn. CRC Press, Boca Raton

Kabata-Pendias A (2004) Soil-plant transfer of trace elementsan environmental issue. Geoderma 122:143-149. https://doi. org/10.1016/j.geoderma.2004.01.004

Kasowska D, Gediga K, Spiak Z (2017) Heavy metal and nutrient uptake in plants colonizing post-flotation copper tailings. Environ Sci Pollut Res 25:824-835. https://doi.org/10.1007/s1135 6-017-0766-8

Keller C, Hammer D (2005) Alternatives for phytoextraction: biomass plants versus hyperaccumulators. Geophys Res Abstr 7:03285

Kononowa MM (1968) Substancje organiczne gleby, ich budowa właściwości i metody badań. PWRiL, Warszawa (in Polish)

Kosiba P (2008) Variability of morphometric leaf traits in smallleaved linden (Tilia cordata Mill.) under the influence of air pollution. Acta Soc Bot Pol 77:125-137. https://doi.org/10.5586/ asbp. 2008.017

Krumins JA, Goodey NM, Gallagher F (2015) Plant-soil interactions in metal contaminated soils. Soil Biol Biochem 80:224-231. https ://doi.org/10.1016/j.soilbio.2014.10.011
Krysiak A, Karczewska A (2011) Effects of soil flooding on arsenic mobility in soils in the area of former gold and arsenic mining in Złoty Stok. Roczniki Gleboznawcze 62:240-248

Krzyżaniak M, Stolarski M, Szczukowski S, Tworkowski J, Bieniek A, Mleczek M (2015) Willow biomass obtained from different soils as a feedstock for energy. Ind Crop Prod 75:114-121. https://doi. org/10.1016/j.indcrop.2015.06.030

MacFarlane GR, Koller CE, Blomberg SP (2007) Accumulation and partitioning of heavy metals in mangroves: a synthesis of field-based studies. Chemosphere 69:1454-1464. https://doi. org/10.1016/j.chemosphere.2007.04.059

Magdziak Z, Gąsecka M, Goliński P, Mleczek M (2015) Phytoremediation and environmental factors. In: Ansari AA, Gill SS, Gill R, Lanza GR, Newman L (eds) Phytoremediation: management of environmental contaminants, vol 1. Springer, Berlin, pp 45-55

Makgalaka-Matlala NS, Flores-Tavizón E, Castillo-Michel H, PeraltaVidea JR, Gardea-Torresdey JL (2008) Toxicity of arsenic (III) and (V) on plant growth, element uptake, and total amylolytic activity of mesquite (Prosopis juliflora $\times$ P. velutina). Int J Phytoremediat 10:47-60. https://doi.org/10.1080/15226510701827069

Manousaki E, Kadukova J, Papadantonakis N, Kalogerakis N (2008) Phytoextraction and phytoexcretion of $\mathrm{Cd}$ by the leaves of Tamarix smyrnensis growing on contaminated non-saline and saline soils. Environ Res 106:326-332. https://doi.org/10.1016/j.envre s.2007.04.004

Marchiol L, Assolari S, Sacco P, Zerbi G (2004) Phytoextraction of heavy metals by canola (Brassica napus) and radish (Raphanus sativus) grown on multicontaminated soil. Environ Pollut 13:2127. https://doi.org/10.1016/j.envpol.2004.04.001

Mayer R (1998) Soil acidification and cycling of metal elements: cause-effect relationships with regard to forestry practices and climatic changes. Agr Ecosyst Environ 67:145-152. https://doi. org/10.1016/S0167-8809(97)00112-6

Mertens J, Vervaeke P, Schrijver AD, Luyssaert S (2004) Metal uptake by young trees from dredged brackish sediment: limitations and possibilities for phytoextraction and phytostabilisation. Sci Total Environ 326:209-215. https://doi.org/10.1016/j.scito tenv.2003.12.010

Mertens J, Van Nevel L, De Schrijver A, Piesschaert F, Oosterbaan A, Tack FMG, Verheyen K (2007) Tree species effect on the redistribution of soil metals. Environ Pollut 149:173-181. https://doi. org/10.1016/j.envpol.2007.01.002

Mleczek M, Magdziak Z, Rissmann I, Goliński P (2009) Effect of different soil conditions on selected heavy metals accumulation by Salix viminalis tissues. J Environ Sci Health A 44:1613-1620. https://doi.org/10.1080/10934520903263645

Mleczek M, Rutkowski P, Niedzielski P, Goliński P, Gąsecka M, Kozubik T, Dąbrowski J, Zalicka S, Pakuła J (2016) The role of selected tree species in industrial sewage sludge/flotation tailing management. Int J Phytoremediat 18:1086-1095. https://doi. org/10.1080/15226514.2016.1183579

Mleczek M, Goliński P, Krzesłowska M, Gąsecka M, Magdziak Z, Rutkowski P, Budzyńska S, Waliszewska B, Kozubik T, Karolewski Z, Niedzielski P (2017) Phytoextraction of potentially toxic elements by six tree species growing on hazardous mining sludge. Environ Sci Pollut Res 24:22183-22195. https://doi.org/10.1007/ s11356-017-9842-3

Mleczek M, Gąsecka M, Waliszewska B, Magdziak Z, Szostek M, Rutkowski P, Kaniuczak J, Zborowska M, Budzyńska S, Mleczek P, Niedzielski P (2018) Salix viminalis L.-a highly effective plant in phytoextraction of elements. Chemosphere 212:67-78. https:// doi.org/10.1016/j.chemosphere.2018.08.055

Munns R (2002) Comparative physiology of salt and water stress. Plant Cell Environ 25:239-250. https://doi.org/10.104 6/j.0016-8025.2001.00808.x 
Nie N, Liu Y, Zeng G, Zheng B, Tan X, Liu H, Xie J, Gan Ch, Liu W (2016) Cadmium accumulation and tolerance of Macleaya cordata: a newly potential plant for sustainable phytoremediation in Cd-contaminated soil. Environ Sci Pollut Res 23:10189-10199. https://doi.org/10.1007/s11356-016-6263-7

Nouri H, Chavoshi Borujeni S, Nirola R, Hassanli A, Beecham S, Alaghmand S, Saint Ch, Mulcahy D (2017) Application of green remediation on soil salinity treatment: a review on halophytoremediation. Process Saf Environ 107:94-107. https://doi. org/10.1016/j.psep.2017.01.021

Oroian IG, Covrig I, Viman O, Odagiu A, Burduhos P, Milăşan A, Şulea C (2012) Testing biomonitoring capacity of trees from urban areas. A case study: $\mathrm{Cu}, \mathrm{Cd}, \mathrm{Pb}, \mathrm{Zn}$ pollution in ClujNapoca, reflected by foliar accumulation of five species located within intense traffic area. Note 1. Results recorded in 2010. ProEnvironment 5:195-199

Pajević S, Borišev M, Nikolić N, Arsenov DD, Orlović S, Župunski M (2016) Phytoextraction of heavy metals by fast- growing trees: a review. In: Ansari AA, Gill SS, Gill R, Lanza GR, Newman L (eds) Phytoremediation: management of environmental contaminants. Springer, Cham, pp 29-64

Pan L, Ma J, Hu Y, Su B, Fang G, Wang Y, Wang Z, Wang L, Xiang B (2016) Assessments of levels, potential ecological risk, and human health risk of heavy metals in the soils from a typical county in Shanxi Province, China. Environ Sci Pollut Res 23:19330-19340. https://doi.org/10.1007/s11356-016-7044-z

Pinto E, Aguiar AARM, Ferreira IMPLVO (2014) Influence of soil chemistry and plant physiology in the phytoremediation of $\mathrm{Cu}, \mathrm{Mn}$, and Zn. Crit Rev Plant Sci 33:351-373. https://doi. org/10.1080/07352689.2014.885729

Plaza S, Tearall KL, Zhao FJ, Buchner P, McGrath SP, Hawkesford MJ (2007) Expression and functional analysis of metal transporter genes in two contrasting ecotypes of the hyperaccumulator Thlaspi caerulescens. J Exp Bot 58:1717-1728. https://doi. org/10.1093/jxb/erm025

Pulford ID, Watson C (2003) Phytoremediation of heavy metal-contaminated land by trees-a review. Environ Int 29:529-540. https ://doi.org/10.1016/S0160-4120(02)00152-6

Richards LA (1954) Diagnostic and improvement of saline and alkali soil. Soil and Water Conservation Research Branch, Agricultural Research Service, Agriculture Handbook no. 60

Rosselli W, Keller C, Boschi K (2003) Phytoextraction capacity of trees growing on a metal contaminated soil. Plant Soil 256:265-272. https://doi.org/10.1023/A:1026100707797

Saba G, Parizanganeh AH, Zamani A, Saba J (2015) Phytoremediation of heavy metals contaminated environments: screening for native accumulator plants in Zanjan-Iran. Int J Environ Res 9:309-316. https://doi.org/10.22059/ijer.2015.902

Serbula SM, Kalinovic TS, Ilic AA, Kalinovic JV, Steharnik MM (2013) Assessment of airborne heavy metal pollution using Pinus spp. and Tilia spp. Aerosol Air Qual Res 13:563-573. https://doi. org/10.4209/aaqr.2012.06.0153

Sheoran V, Sheoran AS, Poonia P (2016) Factors affecting phytoextraction: a review. Pedosphere 26:148-166. https://doi.org/10.1016/ S1002-0160(15)60032-7
Šijačić-Nikolić M, Stanković D, Krstić B, Vilotić D, Ivetić V (2012) The potential of different lime tree (Tilia spp) genotypes for phytoextraction of heavy metals. Genetika-Belgrade 44:537-548. https ://doi.org/10.2298/GENSR1203537S

Šomšák L, Šimurdová B, Lipták J, Kromka M, Antoni J (2000) Accumulation of heavy metals by some forest tree species (Tilia cordata Mill., Acer pseudoplatanus L.). Ekológia 19:324-330

Soudek P, Kinderman P, Maršik P, Petrová Š, Vaněk T (2012) Biomonitoring of air pollution in Prague using tree leaves. J Food Agric Environ 10:810-817. https://doi.org/10.1234/4.2012.3104

Suda A, Makino T (2016) Functional effects of manganese and iron oxides on the dynamics of trace elements in soils with a special focus on arsenic and cadmium: a review. Geoderma 270:68-75. https://doi.org/10.1016/j.geoderma.2015.12.017

Takenaka C, Kobayashi M, Kanaya S (2009) Accumulation of cadmium and zinc in Evodiopanax innovans. Environ Geochem Health 31:609-615. https://doi.org/10.1007/s10653-008-9205-6

Tangahu BV, Sheikh Abdullah SR, Basri H, Idris M, Anuar N, Mukhlisin M (2011) A review on heavy metals (As, $\mathrm{Pb}$, and $\mathrm{Hg}$ ) uptake by plants through phytoremediation. Int J Chem Eng 2011:939161. https://doi.org/10.1155/2011/939161

Telesiński A (2012) The effect of salinity on some biochemical indices of soil fertility. Water Environ Rural Areas 12:209-217 (in Polish)

Theriault G, Nkongogo K (2016) Nickel and copper toxicity and plant response mechanisms in white birch (Betula papyrifera). Bull Environ Contam Toxicol 97(171):176. https://doi.org/10.1007/ s00128-016-1842-3

Unterbrunner R, Puschenreiter M, Sommer P, Wieshammer G, Tlustoš P, Zupan M, Wenzel WW (2007) Heavy metal accumulation in trees growing on contaminated sites in Central Europe. Environ Pollut 148:107-114. https://doi.org/10.1016/j.envpol.2006.10.035

Van Nevel L, Mertens J, Staelens J, De Schrijver A, Tack F, De Neve S, Meers E, Verheyen K (2011) Elevated Cd and Zn uptake by aspen limits the phytostabilization potential compared to five other tree species. Ecol Eng 37:1072-1080. https://doi.org/10.1016/j.ecole ng.2010.07.010

Venturas M, Fernández V, Nadal P, Guzmán P, Lucena JJ, Gil L (2014) Root iron uptake efficiency of Ulmus laevis and U. minor and their distribution in soils of the Iberian Peninsula. Front Plant Sci 5:104. https://doi.org/10.3389/fpls.2014.00104

Vert G, Grotz N, Dédaldéchamp F, Gaymard F, Guerinot ML, Briat JF, Curie C (2002) IRT1, an Arabidopsis transporter essential for iron uptake from the soil and for plant growth. Plant Cell 14:1223-1233. https://doi.org/10.1105/tpc.001388

Wei SH, Zhou QX, Koval PV (2006) Flowering stage characteristics of cadmium hyperaccumulator Solanum nigrum L. and their significance to phytoremediation. Sci Total Environ 369:441-446. https://doi.org/10.1016/j.scitotenv.2006.06.014

Xin J, Huang B, Dai H, Zhou W, Yi Y, Peng L (2015) Roles of rhizosphere and root-derived organic acids in Cd accumulation by two hot pepper cultivars. Environ Sci Pollut Res 22:6254-6261. https ://doi.org/10.1007/s11356-014-3854-z

Yasar U, Ozyigit I, Serin M (2010) Judas tree (Cercis siliquastrum L. subsp. Siliquastrum) as a possible biomonitor for $\mathrm{Cr}, \mathrm{Fe}$, and $\mathrm{Ni}$ in Istambul (Turkey). Rom Biotech Lett 15:4983-4992 